\title{
Bird-termite interactions in Brazil: A review with perspectives for future studies
}

\author{
Marcelo Ferreira de Vasconcelos ${ }^{1}$, Diego Hoffmann ${ }^{2,3}$, Mércia Caroline de Araújo ${ }^{1}$ \& Prinscila Neves Vasconcelos ${ }^{1}$ \\ ${ }^{1}$ Museu de Ciências Naturais, Pontifícia Universidade Católica de Minas Gerais, Avenida Dom José Gaspar \\ 290, Prédio 41, CEP 30535-610, Belo Horizonte, MG, Brazil. \\ ${ }^{2}$ Departamento de Ciências Agrárias e Biológicas, Universidade Federal do Espírito Santo, Rodovia BR 101 \\ Norte, KM 60, Bairro Litorâneo, CEP 29932-540, São Mateus, ES, Brazil. \\ ${ }^{3}$ Corresponding author: Diego Hoffmann, e-mail: diego_hoffmann@hotmail.com
}

VASCONCELOS, M.F., HOFFMANN, D., ARAÚJO, M.C., VASCONCELOS, P.N. Bird-termite interactions in Brazil: A review with perspectives for future studies. Biota Neotropica. 15(1): e20140035. dx. doi.org/10.1590/1676-06032014003514

\begin{abstract}
We present a review on the principal interactions between birds and termites in Brazil. We found 218 bird species feeding on termites or using termitaria for nesting or perching. Termites were mentioned as food source for 179 bird species. Alates were the most consumed caste. Termitaria were mentioned as nest site for 45 bird species. Some bird species also perch on the top of termite mounds to search for their prey or to conduct territorial and/or courtship displays. Considering all interactions between both animal groups, little is known about the identification of termite genera or species. Therefore, we suggest more detailed studies to be conducted on the natural history and ecology of interactions between birds and termites in Brazil.
\end{abstract}

Keywords: birds, Brazil, feeding, nesting, termites.

VASCONCELOS, M.F., HOFFMANN, D., ARAÚJO, M.C., VASCONCELOS, P.N. Bird-termite interactions in Brazil: A review with perspectives for future studies. Biota Neotropica. 15(1): e20140035. dx. doi.org/10.1590/1676-06032014003514

Resumo: Apresentamos aqui uma revisão sobre as principais interações entre aves e cupins no Brasil. Foram registradas 218 espécies de aves alimentando-se de cupins ou usando cupinzeiros para nidificar ou se empoleirar. Os cupins foram citados como recurso alimentar para 179 espécies de aves, sendo as formas aladas as mais consumidas. Os cupinzeiros foram citados como sítio de nidificação para 45 espécies de aves. Algumas espécies de aves também se empoleiram no alto de termiteiros para localizar suas presas ou para realizar exibições territoriais e/ou de corte. Considerando-se todas as interações entre ambos os grupos de animais, pouco ainda se conhece sobre a identificação dos gêneros e espécies de térmitas envolvidos. Assim, sugerimos a realização de estudos mais detalhados sobre história natural e ecologia das interações entre aves e cupins no Brasil.

Palavras-chave: aves, Brasil, alimentação, nidificação, cupins.

\section{Introduction}

Termites (Insecta: Isoptera) have been reported as an important food resource for birds around the world (Eisenmann 1961, De Bont 1964, Thiollay 1970, Dial \& Vaughan 1987, Paiva 1998, Kok et al. 2000, Kopij 2000, Mallet-Rodrigues 2001, Gussoni \& Campos 2003, Olson \& Alvarenga 2006, Faria 2007, Sazima 2008). Termitaria (termite nests) also represent nest sites for several bird species (Hardy 1963, Sazima 1989, Dubs 1992, Naka 1997, Sick 1997, Brightsmith 2000).

Brazil holds one of the richest world avifaunas, with c. 1,800 bird species (Sick 1997, CBRO 2014). Nevertheless, little is known about various aspects of natural history of these species. Examples are the interactions between birds and termites. The $19^{\text {th }}$ century German naturalist, Prince Maximilian of WiedNeuwied explored the Campos Geraës, between the states of Minas Gerais and Bahia, and appears to have been the first to report such observations (Wied-Neuwied 1821).
Later, the German ornithologist Helmut Sick, who visited and stayed in Brazil since 1939 and is one of the leading exponents of Brazilian ornithology of the $20^{\text {th }}$ century, also studied termites when he was a prisoner on Ilha Grande, during the World War II (Gonzaga 1991, Sick 1997). He also remarked the importance of termites either as food as providing shelter for birds and other animals, especially in his study of the Cerrado fauna (Sick 1965) and in his classic book on Brazilian ornithology (Sick 1997).

The naturalist Balthasar Dubs was also devoted to the study of birds in the vegetations of the central-western regions of Brazil. His book on the birds of the Pantanal and adjacent areas (Dubs 1992) presents a discussion on the role of termite mounds in forming the landscape of patches of cerradão or forest in the Pantanal region (the mounds are called "murundus" - for a review of the theories on their role in the landscape formation, see Oliveira-Filho 1992a, b), including photographs of this habitat type. 
Recently, some authors reported termites as a food resource for birds in Brazil (Paiva 1998, Mallet-Rodrigues 2001, Gussoni \& Campos 2003, Olson \& Alvarenga 2006, Faria 2007, Sazima 2008). Nevertheless, studies and information on the interaction between birds and termites in this country are very scarce and fragmentary. The aim of this paper is to present a review on the importance of termites for Brazilian birds and to suggest perspectives for future research.

\section{Materials and methods}

The present review attempted to cover all published information on interactions between birds and termites in Brazil, which includes articles, book chapters, books and photographs available online (www.wikiaves.com.br) until January 2014 (see Table 1). On the Wiki Aves database we searched for photos using the keywords for "foraging", "feeding" and "nest" or "nesting". The principal interactions we found were those related to birds using termites as food resources and termitaria as nest sites or perches. We also included unpublished observations made by several colleagues, as well as some of our personal field observations. Wherever possible, for each record, we considered the lowest taxonomic level of identification of the termites, the castes involved (alates, soldiers and workers - in the case of food resource) and the type of termite nest, according to the building site: epigean or mound; arboreal (supported on a tree or similar); rupicolous (upon a rock). Taxonomy of bird species follows the Comitê Brasileiro de Registros Ornitológicos (CBRO 2014).

\section{Results and Discussion}

\section{General inventory of bird-termite interactions in Brazil}

We found a total of 218 bird species that use the termites in a direct way (food resource) or indirectly (such as the use of termitaria as nesting or perching sites) (Table 1). This number represents approximately only c. $12 \%$ of Brazilian the avifauna (Sick 1997, CBRO 2014). Below, we present and discuss each of these types of interactions.

\section{Termites as food resource for Brazilian birds}

Termites have been reported as food resource for 179 species of birds in Brazil, of 51 families (Table 1). The families with the largest number of bird species feeding on termites are: Thraupidae (29 species), Tyrannidae (25), Picidae (11) and Thamnophilidae (10) (Figure 1).

Little is known about the taxonomic groups of termites consumed by birds. Among the 277 records, in 189 (68.2\%) termites were identified at order level; in 50 (18.1\%), at the family level; in $33(11.9 \%)$, at the genus level and only in 5 $(1.8 \%)$, at specific level (Figure 2).

Considering the different castes consumed by birds, among the 290 records, $189(65.2 \%)$ report alates, $17(5.9 \%)$ are related to soldiers and $15(5.2 \%)$ mention workers. In 69 records (23.7\%), castes were not mentioned (Figure 3).

Thus, alates seem to represent the main caste consumed by birds. But the problem is that swarms are unpredictable events in space and time, so that winged termites represent a resource that should be exploited in an opportunistic manner. Predation of alates by birds has been studied in more details in Africa (e.g., De Bont 1964, Thiollay 1970, Dial \& Vaughan 1987, Kok et al. 2000, Kopij 2000). Unfortunately, little has been studied about this interaction in Brazil. For example, opportunistic information was reported by Cunha (1961), who observed a domestic hen, swallows and tyrant-flycatchers feeding on winged termites. In September 1989, Paiva (1998) observed 12 species of birds preying alates in an urban park in Piracicaba/SP.

Gussoni \& Campos (2003) reported 26 species of birds feeding on alates in Arujá/SP, in January 2002.

In the montane forests of the Serra da Mantiqueira, in April 2001, Olson \& Alvarenga (2006) observed 23 species of birds feeding on winged termites. In this event, they recorded many specimens of the Buff-throated Warbling-Finch (Poospiza lateralis), a species endemic to the high mountains of southeastern Brazil (Assis et al. 2007). Further, three Black-capped Piprites (Piprites pileata), a threatened species (BirdLife International 2000, Machado et al. 2005), were also feeding on alates. The authors observed that several species that commonly forage on the ground or among bushes were catching those termites in the air during this event.

In the same mountain range, in December 2002, C. R. M. Abreu and M. Maldonado-Coelho (pers. comm.) observed alates swarming after rain, in a transitional area of montane forest and high-altitude grassland (campo de altitude), in Matutu Valley (elevation: 1,990 m), Aiuruoca/MG. Six bird species were consuming these insects: the Highland Elaenia (Elaenia obscura), the Blue-billed Black-Tyrant (Knipolegus cyanirostris), the Blue-and-white Swallow (Pygochelidon cyanoleuca), the Diademed Tanager (Stephanophorus diadematus), the Rufous-collared Sparrow (Zonotrichia capensis) and the Bay-chested Warbling-Finch (Poospiza thoracica). Pygochelidon cyanoleuca captured termites in flight, while $K$. cyanirostris, $Z$. capensis and $P$. thoracica catched insects among leaves (in the forest edge) and in the bushes (in the grassland). Elaenia obscura and $S$. diadematus captured termites both in flight, as well as among the foliage.

Also in the Serra da Mantiqueira, a termite swarm was observed after a light rain in the late afternoon of 27 March 2007, in a transition area between a montane forest and the campo de altitude at Pedra de São Domingos (elevation: c. 1,970 $\mathrm{m})$, in Gonçalves/MG (MFV pers. obs.). Only one specimen of $Z$. capensis and two individuals of $P$. lateralis were observed feeding on the winged termites among the foliage.

In November 2001, MFV and S. D'Angelo-Neto observed a swarm in Lavras/MG. Alates were flying in the edge of a secondary forest and adjacent open areas (pastures), being captured by the domestic Helmeted Guineafowl (Numida meleagris, $\mathrm{n}=2$ ), and the following native species: Greenbarred Woodpecker (Colaptes melanochloros, $\mathrm{n}=1$ ), Rufous Hornero (Furnarius rufus, $\mathrm{n}=2$ ), Masked Water-Tyrant (Fluvicola nengeta, $\mathrm{n}=2$ ), Social Flycatcher (Myiozetetes similis, $\mathrm{n}=1$ ), Boat-billed Flycatcher (Megarynchus pitangua, $\mathrm{n}$ $=1$ ), Streaked Flycatcher (Myiodynastes maculatus, $\mathrm{n}=1$ ), Variegated Flycatcher (Empidonomus varius, $\mathrm{n}=1$ ), Crested Becard (Pachyramphus validus, $\mathrm{n}=1$ ), Hooded Tanager (Nemosia pileata, $\mathrm{n}=2$ ), Pileated Finch (Lanio pileatus, $\mathrm{n}=$ 1), Sayaca Tanager (Tangara sayaca, $\mathrm{n}=3$ ), Swallow Tanager (Tersina viridis, $\mathrm{n}=2$ ), Rufous-collared Sparrow $(\mathrm{n}=1)$, Saffron Finch (Sicalis flaveola, $\mathrm{n}=2$ ), Crested Oropendola (Psarocolius decumanus, $\mathrm{n}=1$ ) and Shiny Cowbird (Molothrus bonariensis, $\mathrm{n}=1$ ). Except $F$. nengeta, $Z$. capensis and $L$. pileatus, which caught the alates when they landed on the ground, all other species caught insects in the air. The Helmeted 


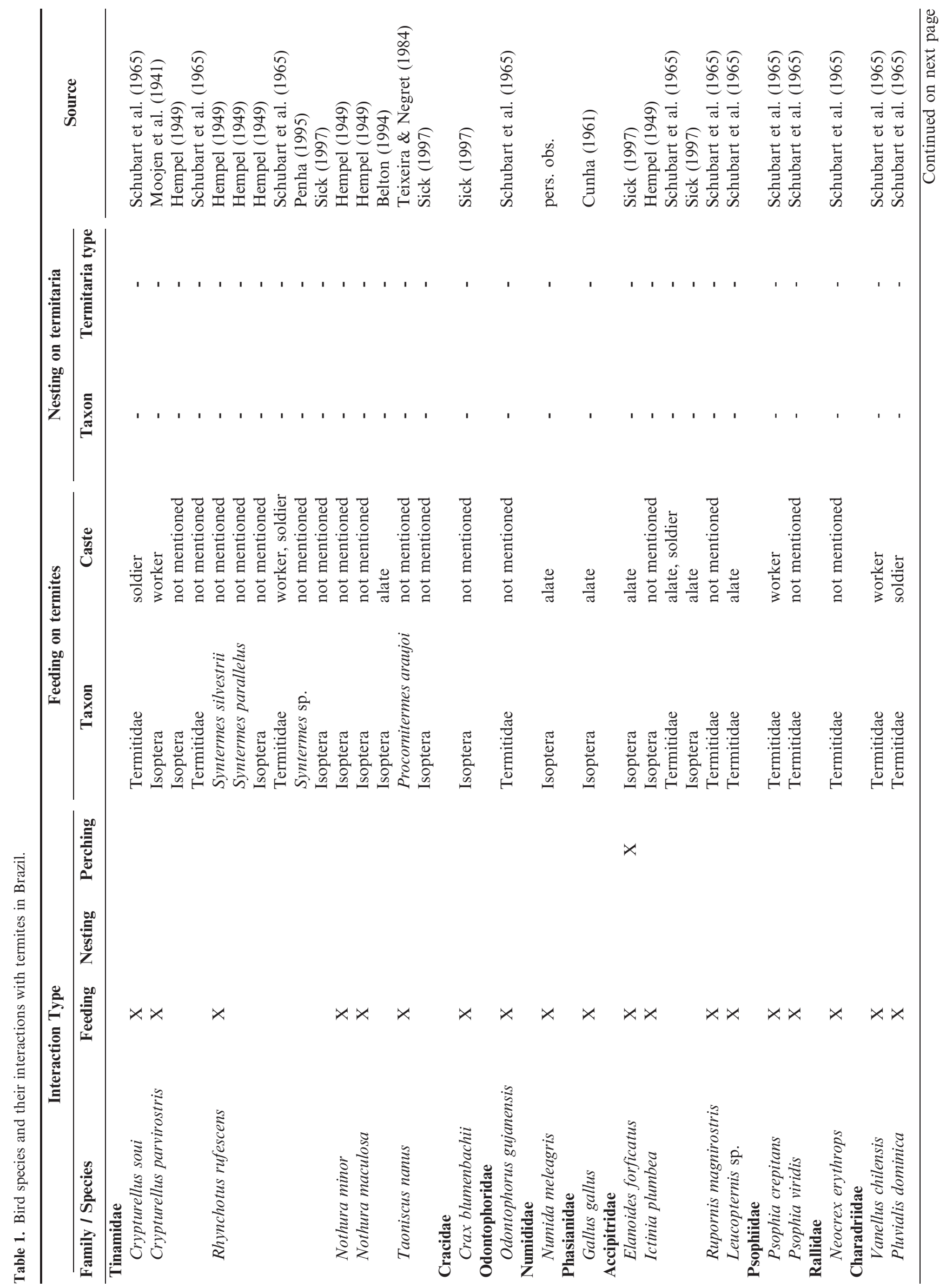




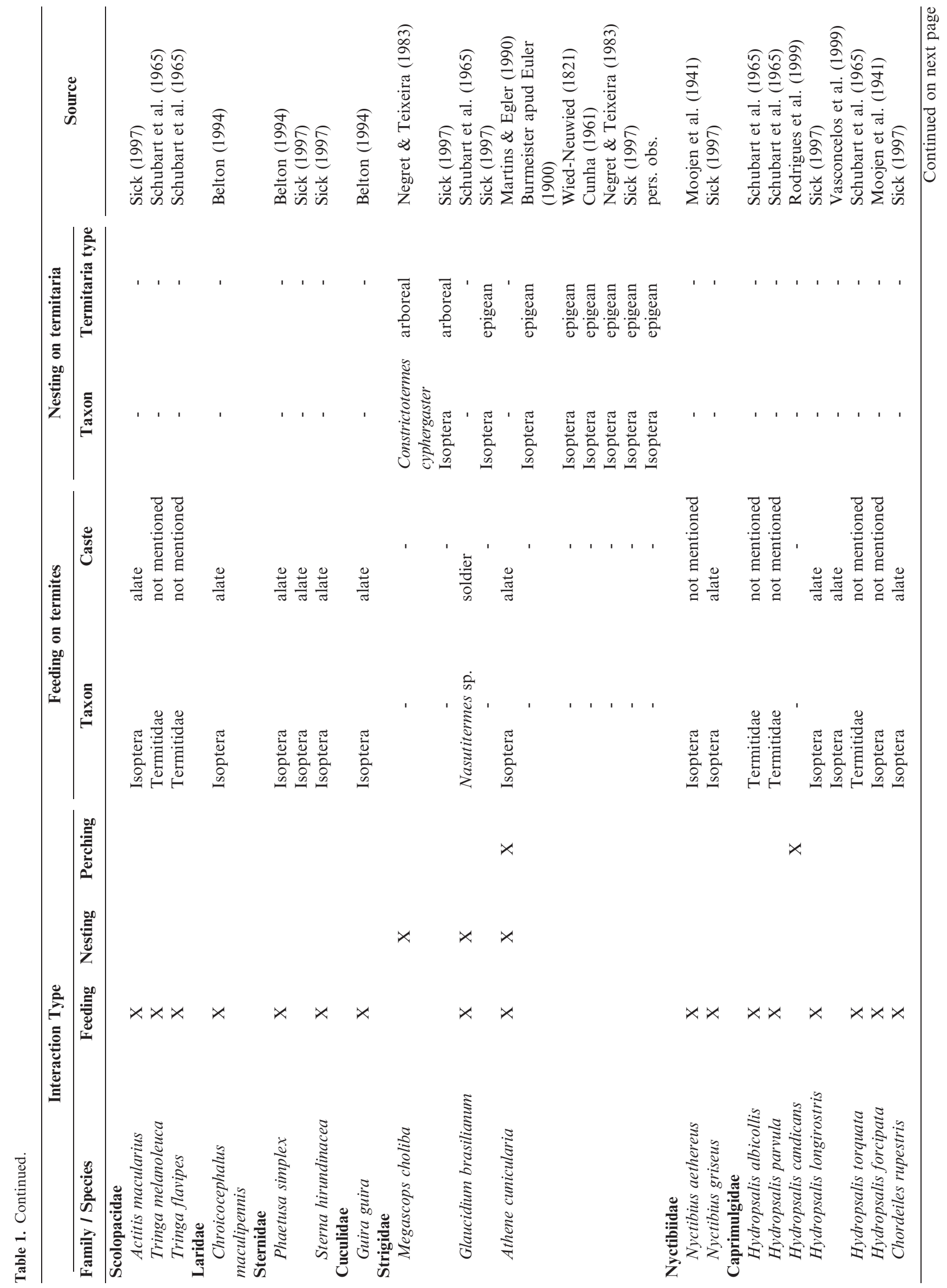


Bird-termite interactions in Brazil: A review

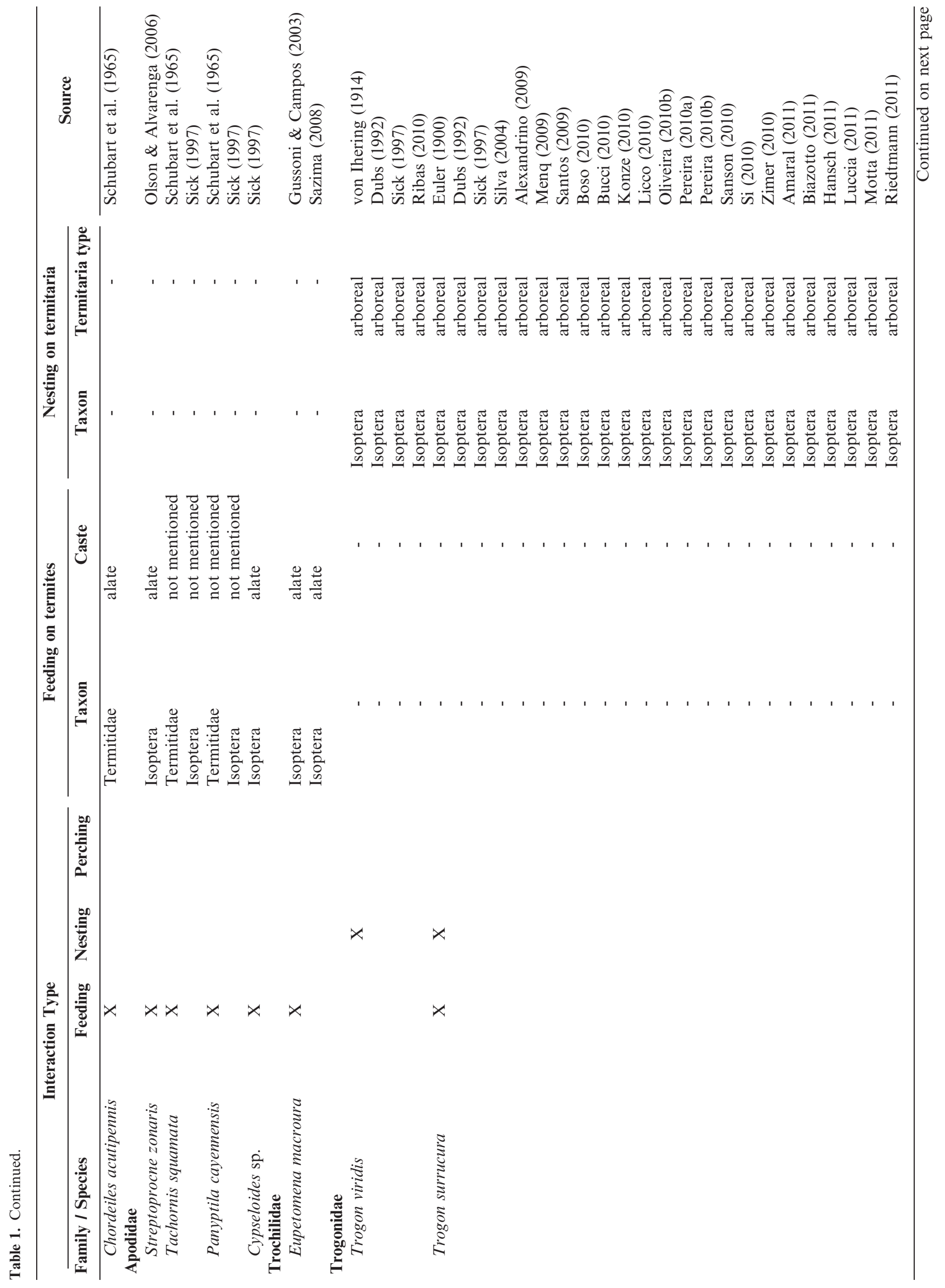




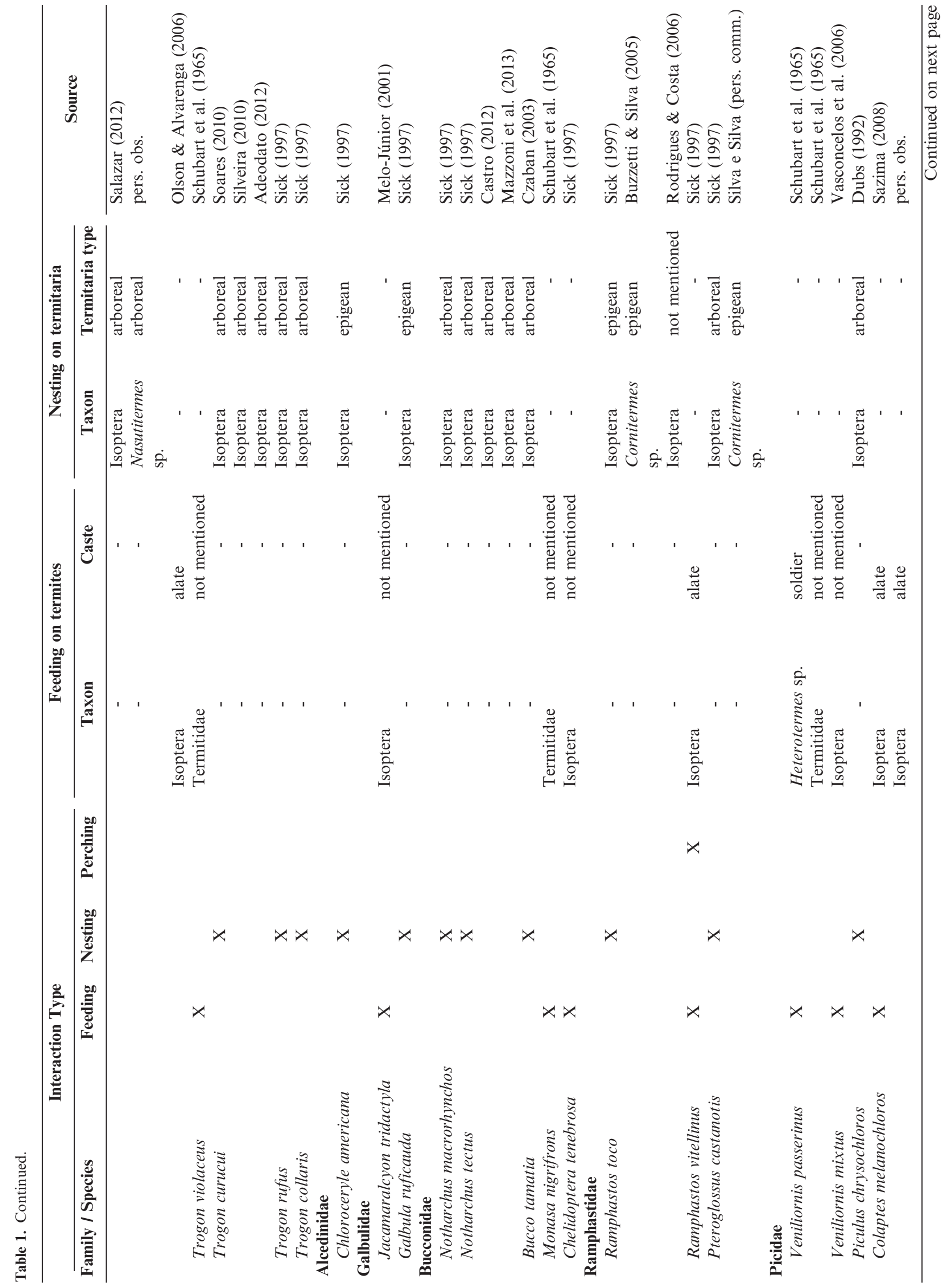


Bird-termite interactions in Brazil: A review

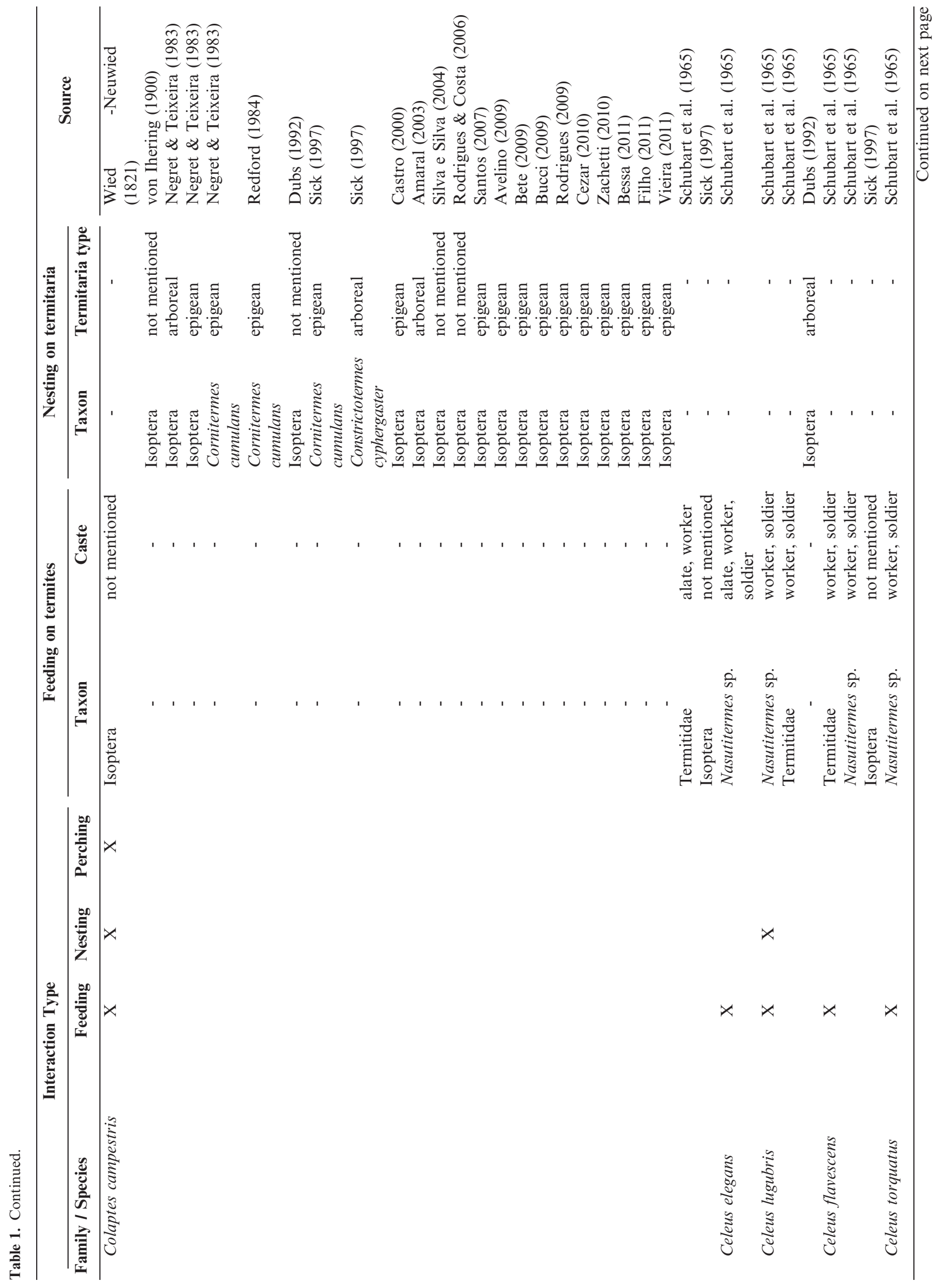




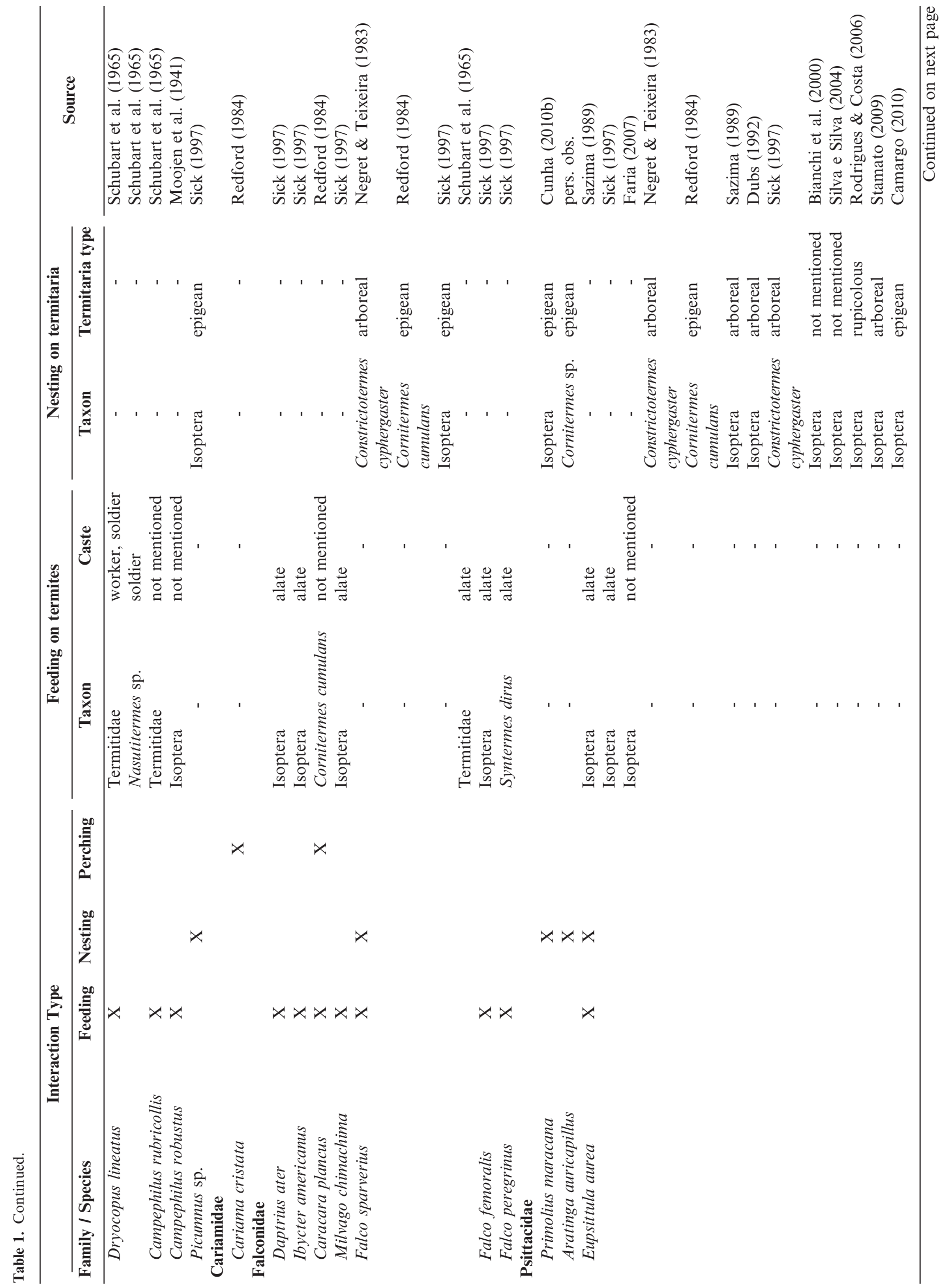




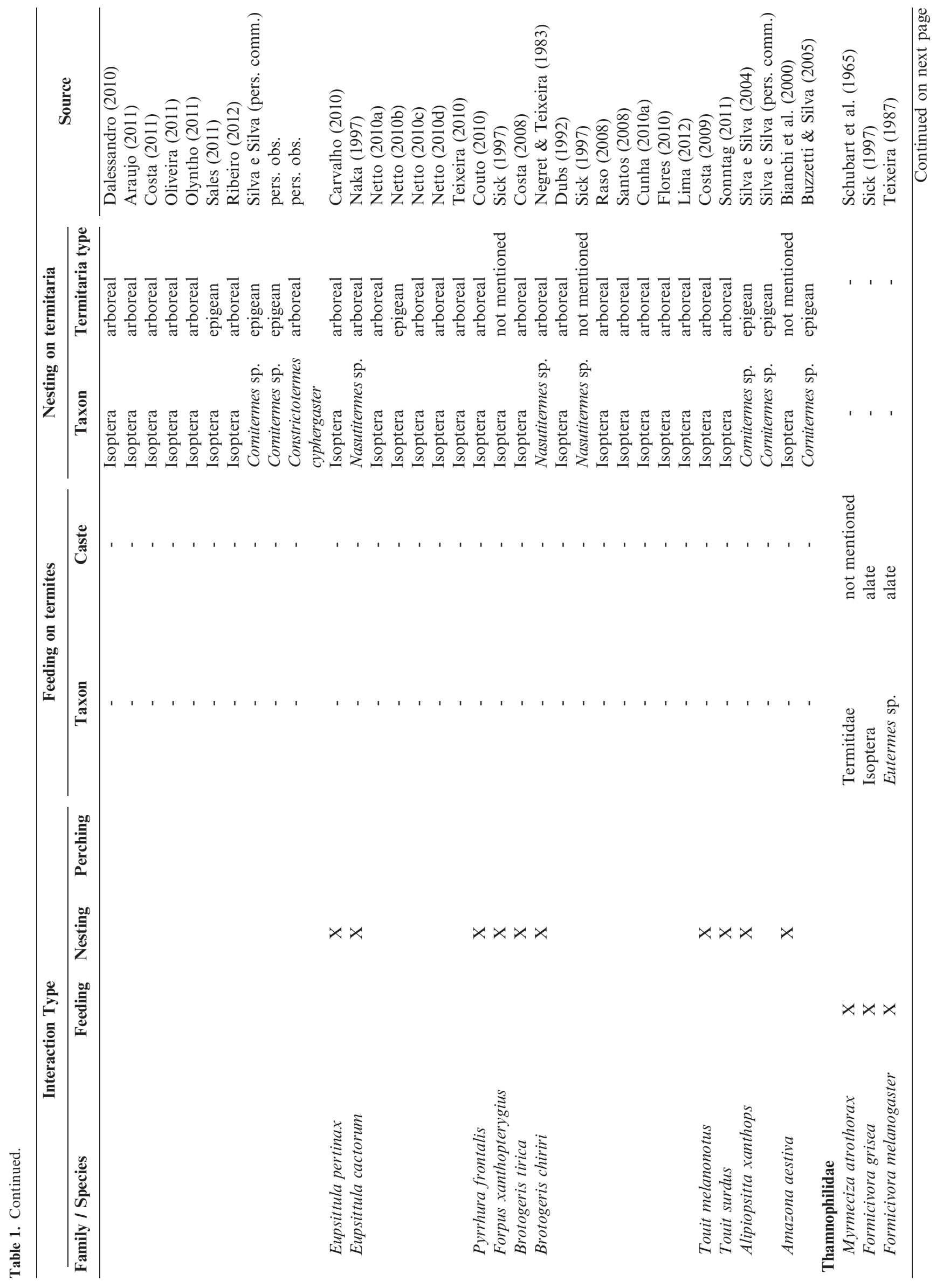




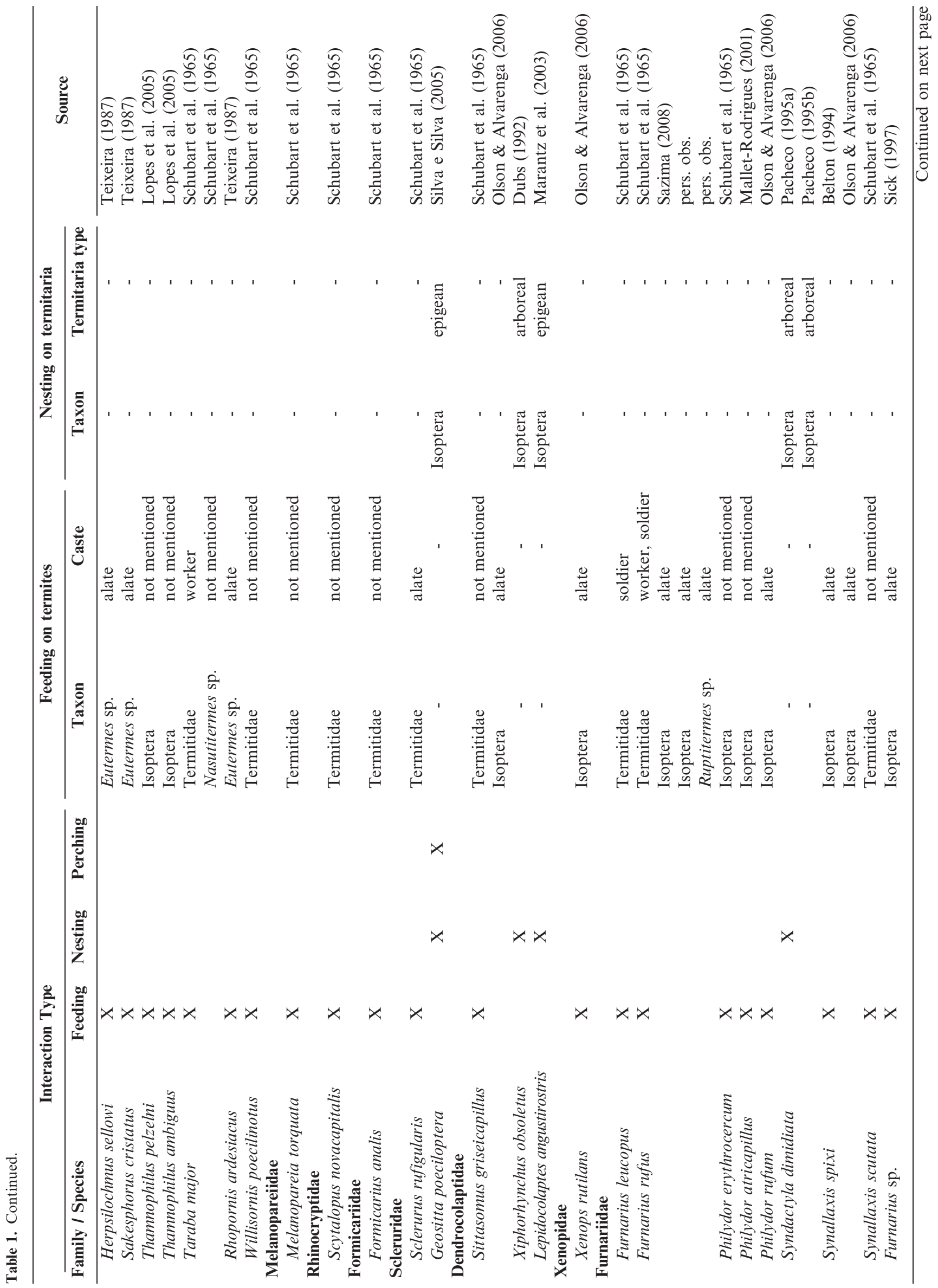




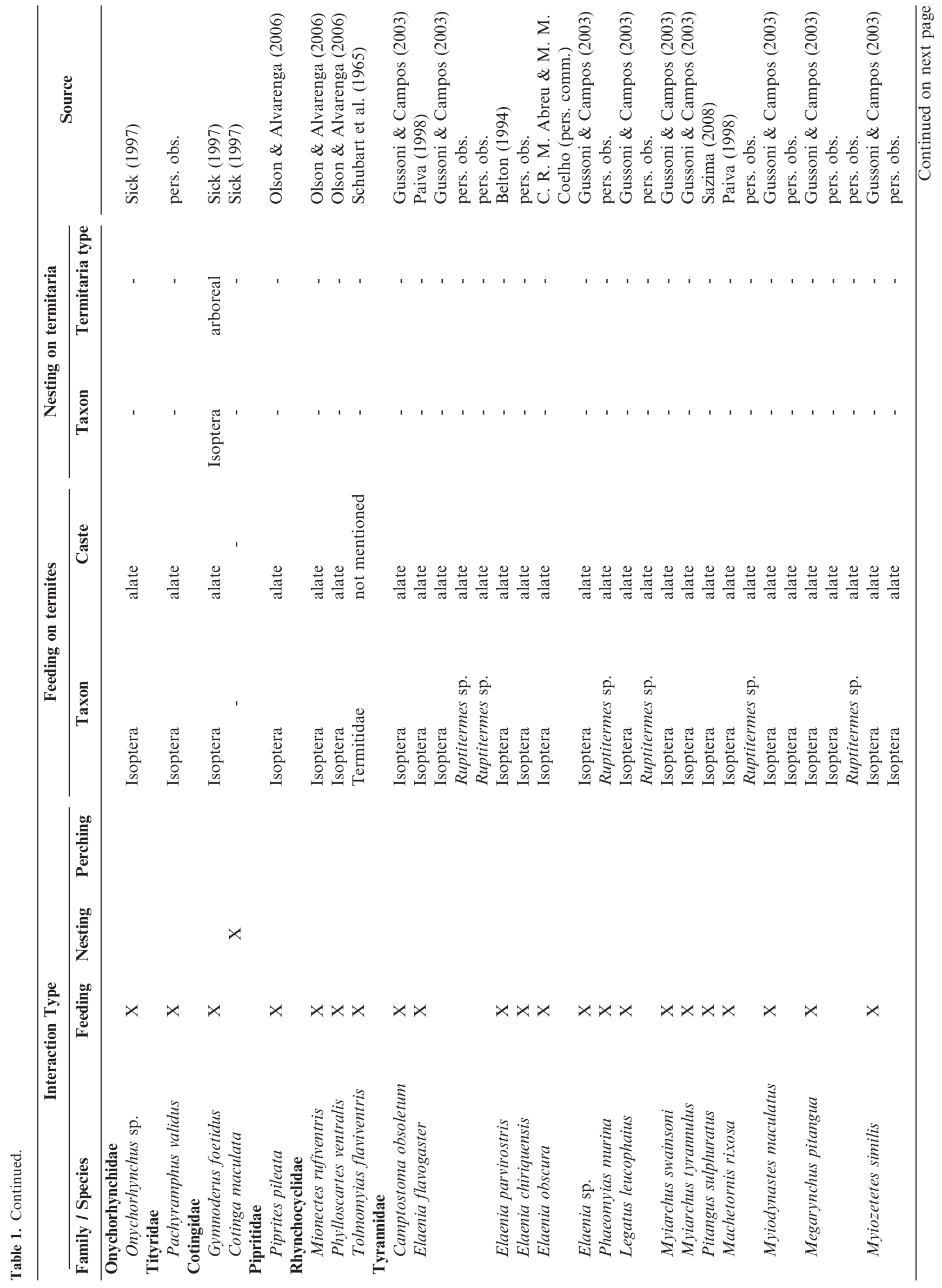




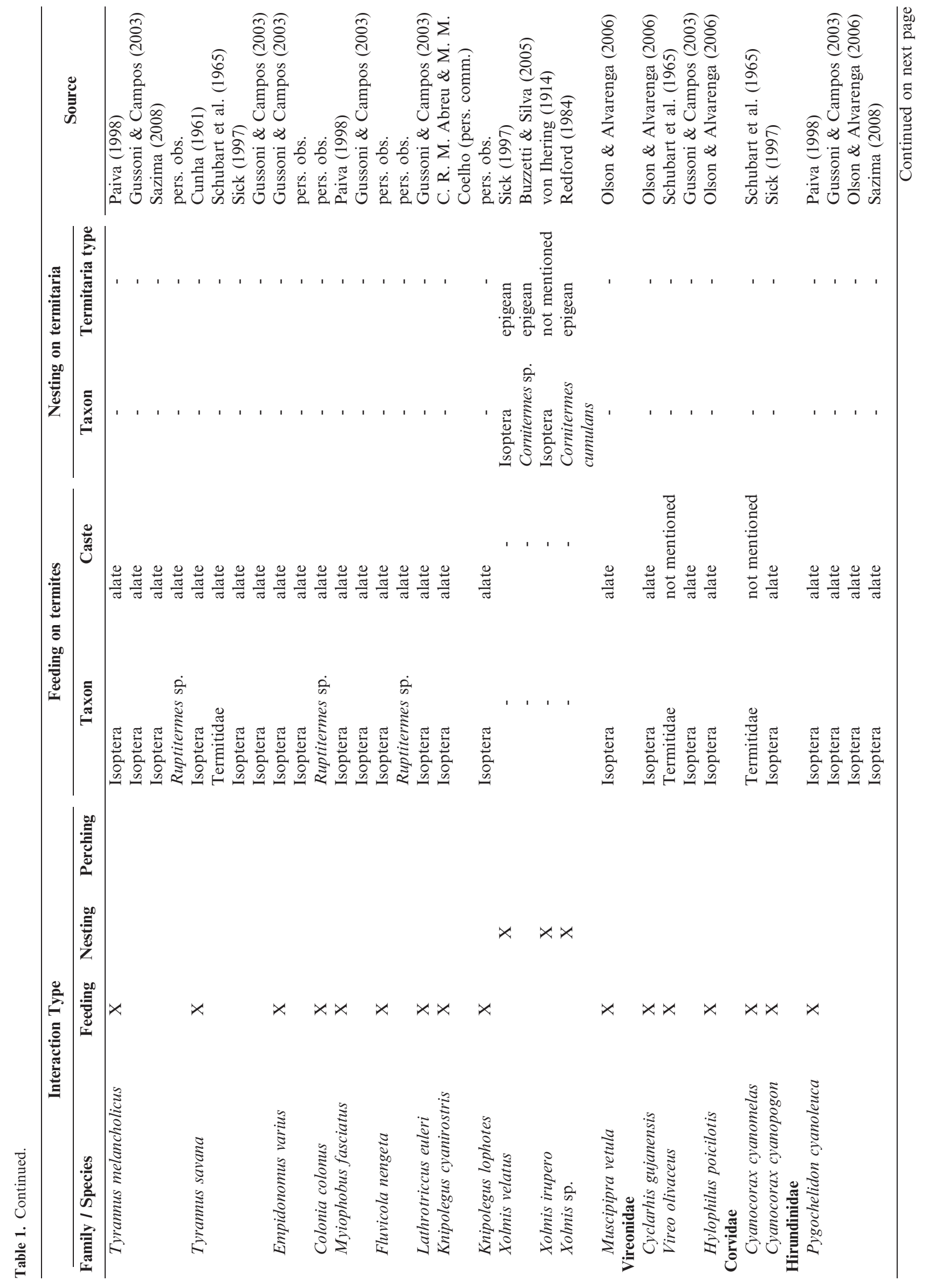


Bird-termite interactions in Brazil: A review

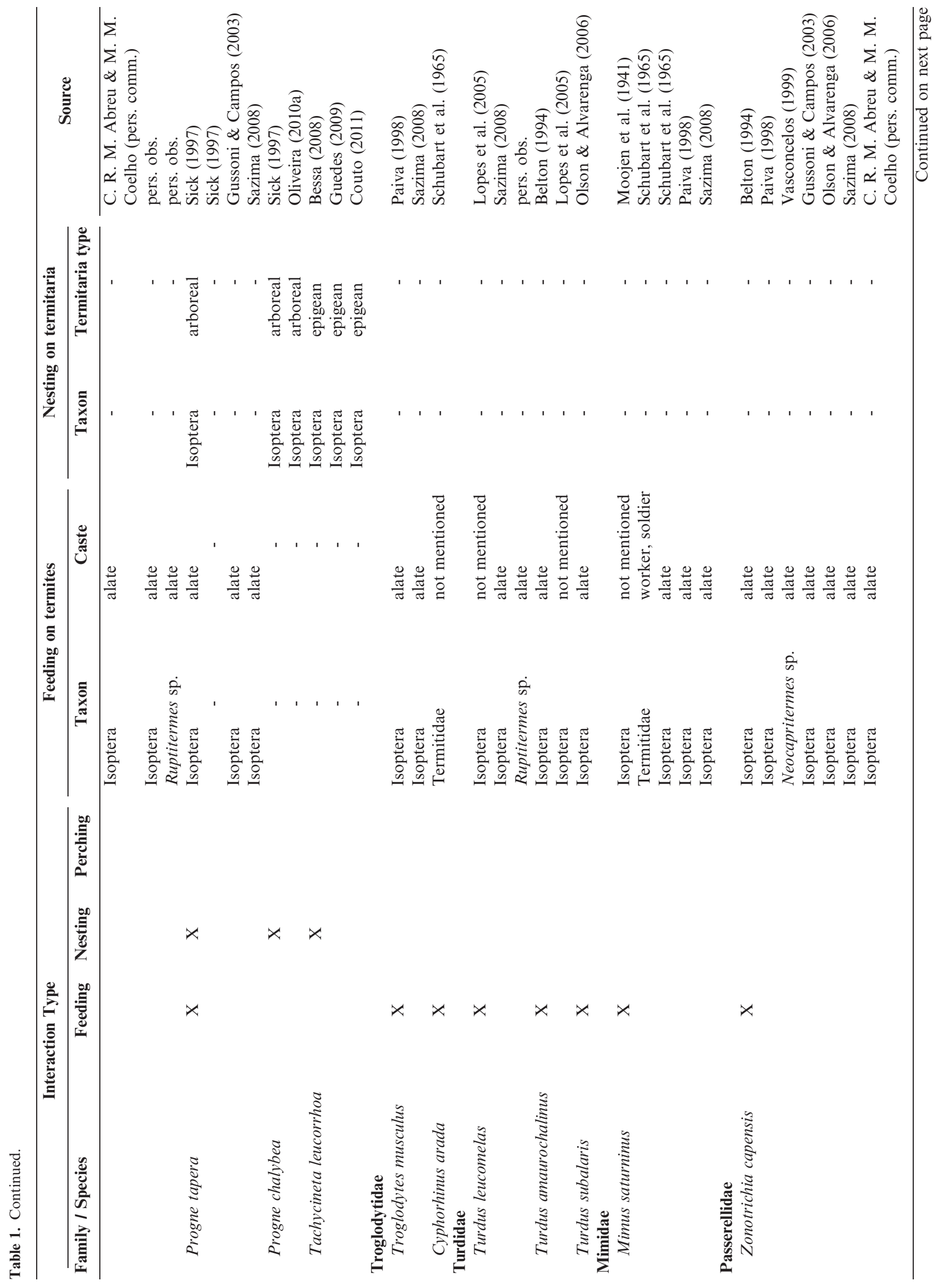




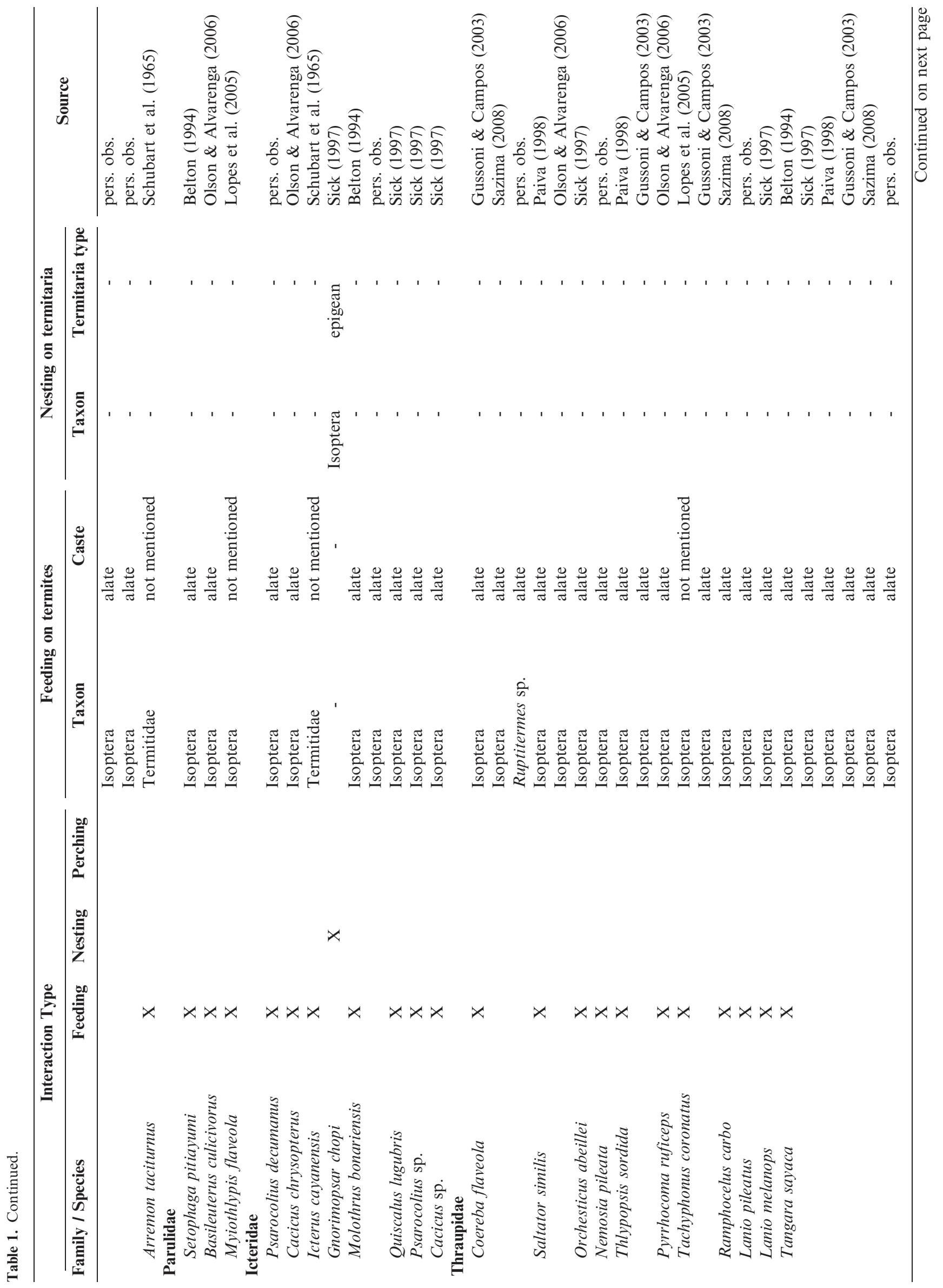


Bird-termite interactions in Brazil: A review

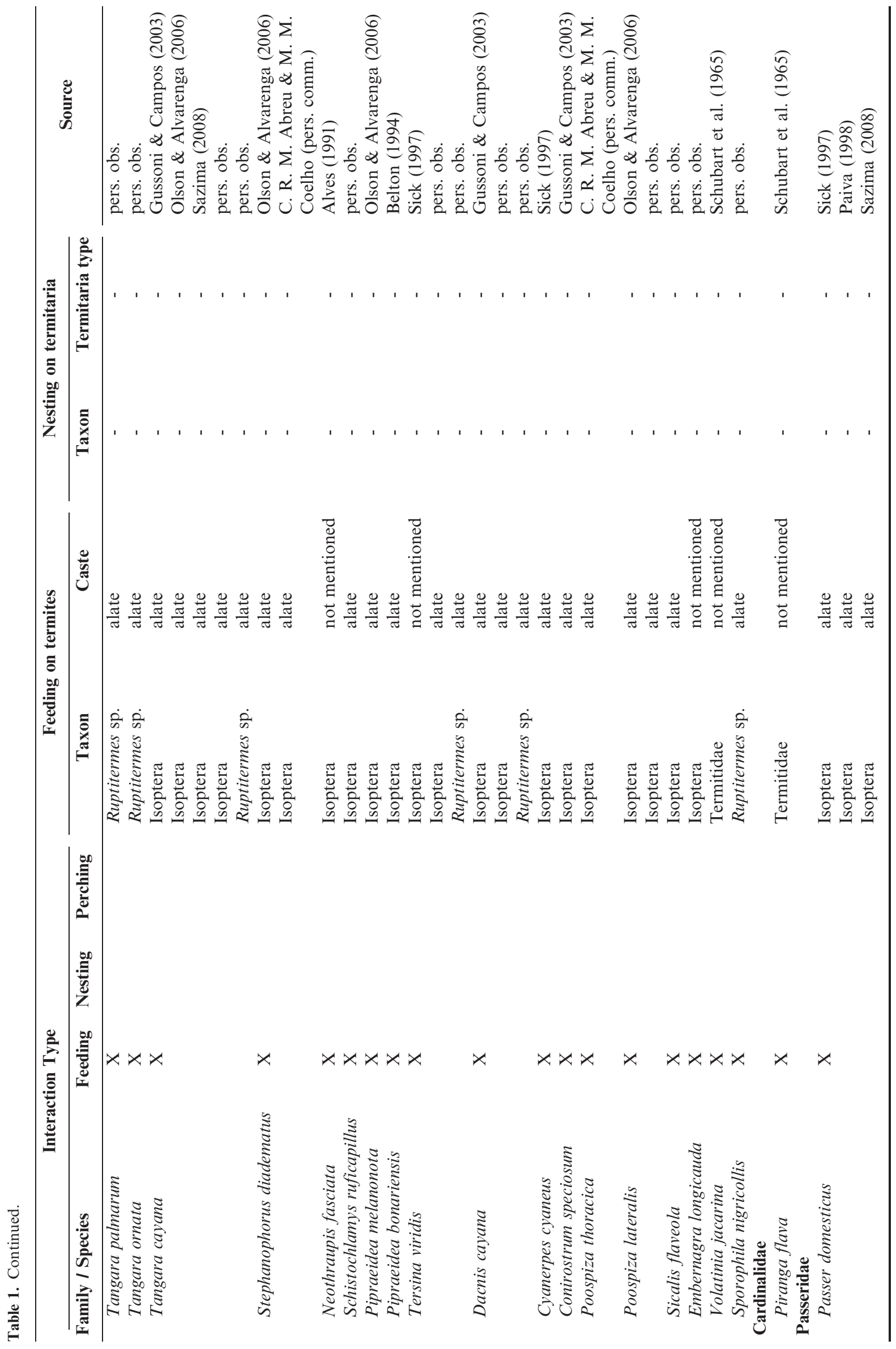




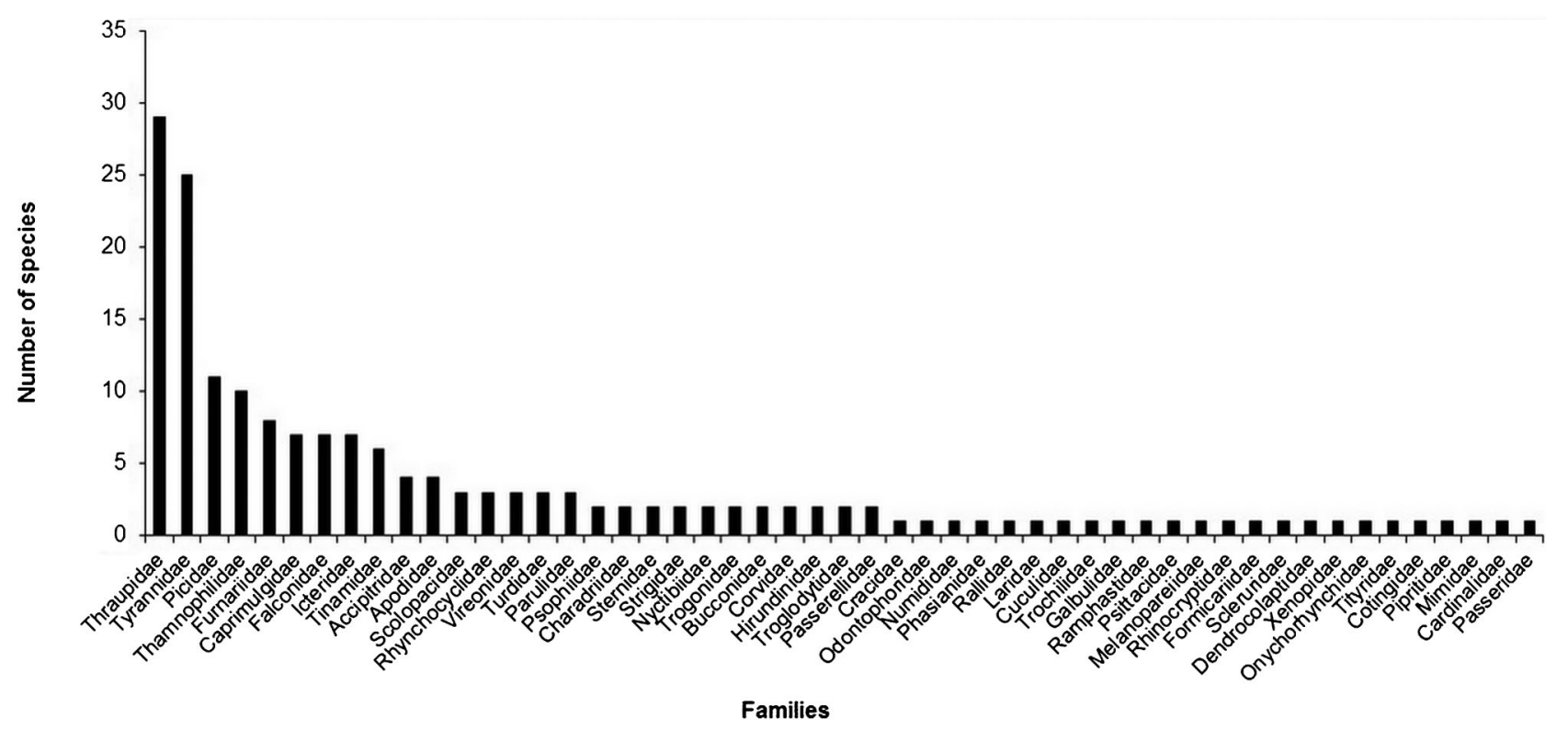

Figure 1. Number of bird species, per family, recorded feeding on termites in Brazil.

Guineafowl, despite being a terrestrial species, jumped and caught the termites in flight. Although it is a domestic and exotic species, it also feeds on termites in wildlife, as recorded by Thiollay (1970) in Africa.

In the course of another swarm, observed in December 2005 at a grassland savannah (campo cerrado), in the Serra do Mascate, Congonhas/MG, MFV (pers. obs.) recorded the following species of birds feeding on winged termites: Lesser Elaenia (Elaenia chiriquensis, $\mathrm{n}=1$ ), Crested Black-Tyrant (Knipolegus lophotes, $\mathrm{n}=1)$, Blue-and-white Swallow $(\mathrm{n}=5)$, Cinnamon Tanager (Schistochlamys ruficapillus, $\mathrm{n}=2$ ), Sayaca Tanager $(\mathrm{n}=2)$, Burnished-buff Tanager (Tangara cayana, $\mathrm{n}=$ 3 ) and Blue Dacnis (Dacnis cayana, $\mathrm{n}=2$ ).

On 22 January 2008, at c. 17:30 h, MFV and L. N. Souza observed a swarm of Ruptitermes sp. at a light rain in Fazenda Bocaina ( $20^{\circ} 00^{\prime} 01^{\prime \prime} \mathrm{S}, 43^{\circ} 28^{\prime} 17^{\prime \prime} \mathrm{W}$; elevation: c. $\left.750 \mathrm{~m}\right)$, Santa Bárbara/MG. The alates were emerging from a hole in the soil of an orchard, protected by workers. Birds of the following species were observed catching these winged termites: Rufous Hornero $(\mathrm{n}=2)$, Yellow-bellied Elaenia (Elaenia

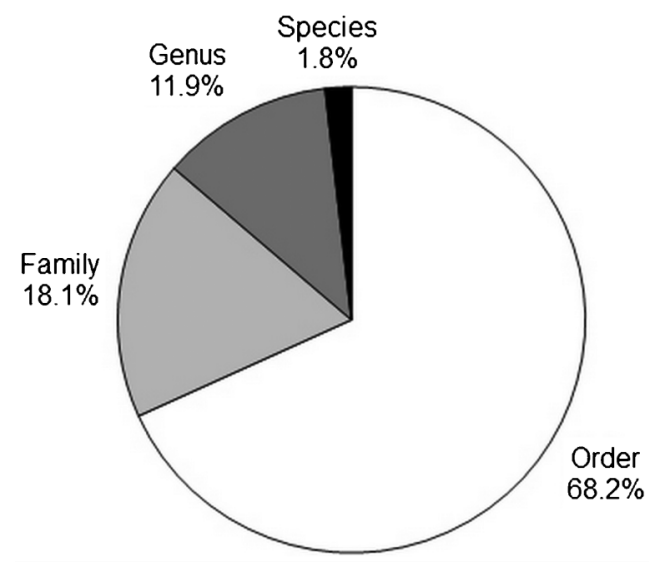

Figure 2. Percentages of identification, in different taxonomic levels, of the termites recorded as food resource for birds in Brazil. flavogaster, $\mathrm{n}=1)$, Masked Water-Tyrant $(\mathrm{n}=1)$, Long-tailed Tyrant (Colonia colonus, $\mathrm{n}=1$ ), Cattle Tyrant (Machetornis rixosa, $\mathrm{n}=1$ ), Piratic Flycatcher (Legatus leucophaius, $\mathrm{n}=1$ ), Boat-billed Flycatcher $(\mathrm{n}=1)$, Tropical Kingbird (Tyrannus melancholicus, $\mathrm{n}=1)$, Blue-and-white Swallow $(\mathrm{n}=1)$, Palebreasted Thrush (Turdus leucomelas, $\mathrm{n}=1$ ), Bananaquit (Coereba flaveola, $\mathrm{n}=1$ ), Palm Tanager (Tangara palmarum, $\mathrm{n}=2$ ), Golden-chevroned Tanager (Tangara ornata, $\mathrm{n}=2$ ), Burnished-buff Tanager $(n=2)$ and Swallow Tanager $(n=2)$. Interestingly, several birds that usually do not perform aerial foraging tactics, such as: E. flavogaster, T. leucomelas, $T$. ornata, T. palmarum, T. cayana and T. viridis, caught insects in flight, landing later to consume them. In the case of T. viridis, the same specimen (a male) captured up to five alates in a single attempt. Megarynchus pitangua and C. flaveola captured winged termites that landed in trees and shrubs. One specimen of T. cayana combined both foraging techniques (in flight and perched in the shrubs). Birds that usually forage on the ground caught alates that were still on the ground, such as: F. rufus, $F$. nengeta and M. rixosa.

Around 17:00 h, on 28 January 2008, another swarm of Ruptitermes $\mathrm{sp}$. was observed by MFV and L. N. Souza in a

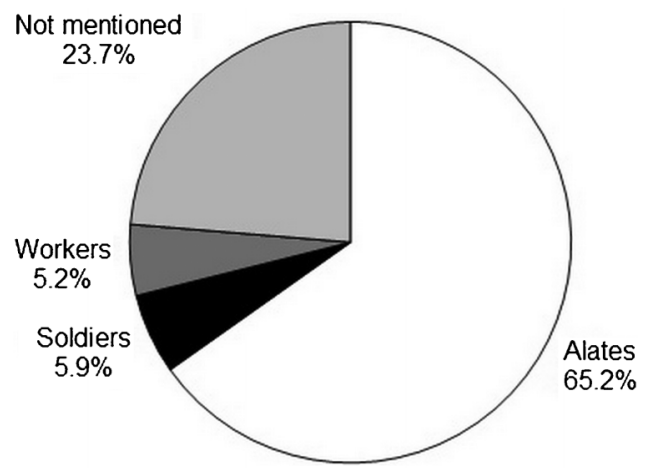

Figure 3. Percentage of termite castes recorded as food resource by birds in Brazil. 


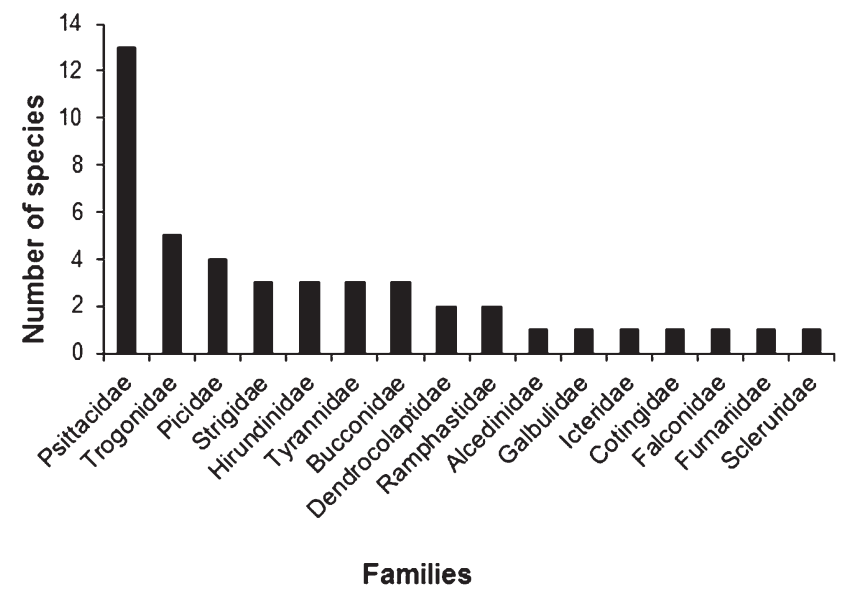

Figure 4. Number of bird species, per family, using termitaria as nesting sites in Brazil.

secondary forest edge at Córrego do Sítio $\left(20^{\circ} 00^{\prime} 36^{\prime \prime} \mathrm{S}, 43^{\circ}\right.$ $30^{\prime} 45^{\prime}$ ' W), also in Santa Bárbara/MG. The following species of birds captured insects in flight: Yellow-bellied Elaenia $(\mathrm{n}=$ 1), Mouse-colored Tyrannulet (Phaeomyias murina, $\mathrm{n}=1$ ), Blue Dacnis ( $\mathrm{n}=2$; a couple) and Yellow-bellied Seedeater (Sporophila nigricollis, $\mathrm{n}=2$; a couple).

In a recent paper, Sazima (2008) also reported 16 bird species feeding on alates in Campinas/SP, in July 2007. He also noted the changing of regular foraging behavior of several species as pointed out by Olson \& Alvarenga (2006).

The flight activity is unknown for most termites. Although not a rule, in southeastern Brazil swarmings generally occur from the end of the dry season to the beginning of the rainy season (between September and March), but in some parts of the Amazon region the effects of seasonality are less pronounced (Silvestri 1903, Costa-Lima 1938, Martius et al. 1996, Medeiros et al. 1999). It is noteworthy that most termite swarms seems to coincide with the breeding season of birds, i.e. the beginning of the rainy season. As alates are rich in proteins and lipids (Nutting 1969), their predation during the breeding season of birds seems to be important to supplement their energy and protein demands. The Rufous-collared Sparrow was recorded feeding on alates of Neocapritermes sp. at the time that this species reproduces in the central state of Minas Gerais (Vasconcelos 1999). Melo-Júnior (2001) observed the Threetoed Jacamar (Jacamaralcyon tridactyla), a rare bird species endemic to the Atlantic Forest, also feeding on termites during its breeding season.

In the case of ground-foraging birds, such as the Redwinged Tinamou (Rhynchotus rufescens) and the Dwarf Tinamou (Taoniscus nanus), there are reports that these species dig termite mounds with their beaks to feed on those insects (Teixeira \& Negret 1984, Sick 1997). Sick (1997) mentioned that this work is facilitated when mounds were previously damaged by other predators (such as anteaters) and repaired by termites with still fresh material. Other species of tinamous (Tinamidae) probably also exhibit this behavior, but have not yet been observed. When birds dig termite mounds, they can feed on other castes (workers and soldiers) and immatures (as nymphs, which are rich in fat and protein). Probably, the termites also enrich the diet of other groups of flying birds that burrow into

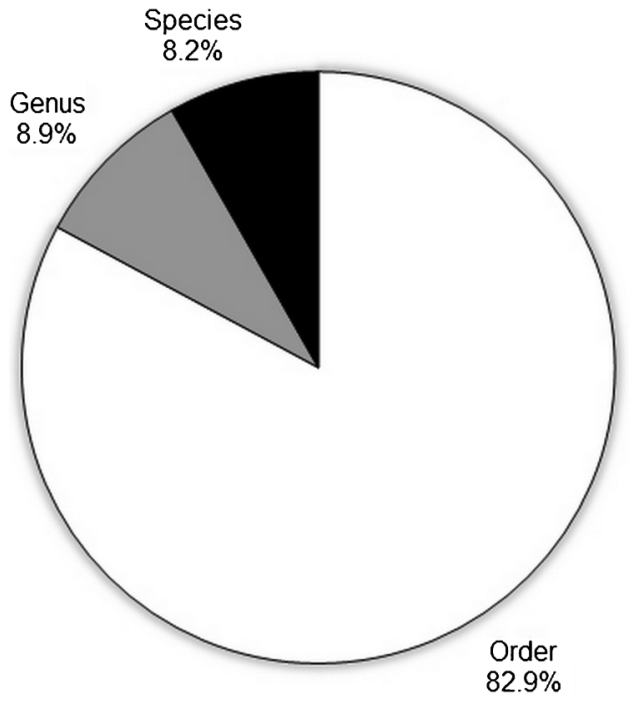

Figure 5. Percentages of identification, in different taxonomic levels, of the termites that build termitaria used as nest site by birds in Brazil.

mounds for nesting sites, such as parrots (Psittacidae), woodpeckers (Picidae) and trogons (Trogonidae) (see Euler 1900, Schubart et al. 1965, Sazima 1989, Dubs 1992, Naka 1997, Sick 1997).

\section{Termitaria as nest sites for Brazilian birds}

Termitaria were recorded as nesting sites for 45 species of Brazilian birds of 16 families (Table 1). The most representative families are: Psittacidae (13 species), Trogonidae (5), Picidae (4), Strigidae, Hirundinidae, Bucconidae and Tyrannidae (3) (Figure 4). These families are represented by several species that nest in holes in trees or natural walls. In general, birds of the families Alcedinidae (kingfishers) and Galbulidae (jacamars) nest in holes dug into ravines, being noteworthy Sick's (1997) observations on one species of each family nesting in termite mounds.

Again, little is known about the termite species that build termitaria used by birds as nest sites. Among the 146 records, in $121(82.9 \%)$ termites were identified at the order level; in 13 $(8.9 \%)$, at the generic level and only in $12(8.2 \%)$, at species level (Figure 5).

Concerning the types of termitaria used by birds, from 146 records, $84(57.5 \%)$ are arboreal, $50(34.3 \%)$ are epigean and only one $(0.7 \%)$ is rupicolous. In 11 records $(7.5 \%)$ termitaria types were not mentioned (Figure 6). In the only record of rupicolous mound, Rodrigues \& Costa (2006) described the Peach-fronted Parakeet (Eupsittula aurea) nesting on a termitaria built on rocky walls of a canyon in the Serra do Cipó/MG.

Nesting inside termitaria can offer advantages to birds, as protection against predators and propitious micro-climate (Sick 1997). However, it is not always possible to know whether a bird that nests inside the termitaria dig its own nest or use a cavity excavated by another bird. Woodpeckers (Picidae), parrots (Psittacidae), trogons (Trogonidae) and puffbirds (Bucconidae) were reported excavating termitaria for nesting (Sazima 1989, Dubs 1992, Sick 1997). On the afternoon of 6 August 1999, for about 15 minutes, MFV observed a male of the Surucua Trogon (Trogon surrucura surrucura) digging an arboreal termitarium of Nasutitermes sp. at Morro do Diabo State Park, Teodoro Sampaio/SP. This termitarium was about 


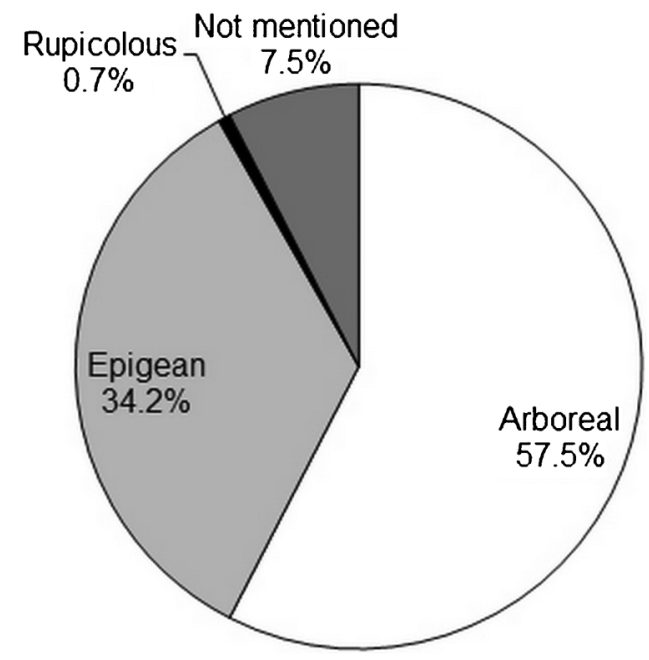

Figure 6. Percentages of termitaria types used by birds as nest sites in Brazil.

$3 \mathrm{~m}$ above the ground in a tree at the edge of secondary forest. The bird perched on the termitarium like a woodpecker, grabbed by its feet. It also used its tail as a support, worning its rectrices (Figure 7). The female remained perched in a nearby tree and watched the work carried out by the male, without participating in the excavation.

Among parrots, R. Silva e Silva (pers. comm.) observed the following bird species nesting in mounds of Cornitermes sp.: Peach-fronted Parakeet (in Tapira/MG) and Yellow-faced Parrot (Alipiopsitta xanthops; at Emas National Park, Mineiros/GO). In the cerrado region of Minas Gerais state, the Peach-fronted Parakeet is also commonly observed nesting in arboreal termite nests of Constrictotermes cyphergaster, in Sete Lagoas, Paraopeba and Inhaúmas (Figure 8). This parakeet was recorded nesting in these termitaria between the months of April and July (MFV pers. obs.).

It is noteworthy that termites restore the termitaria walls that were excavated by birds, but generally respects the birds'

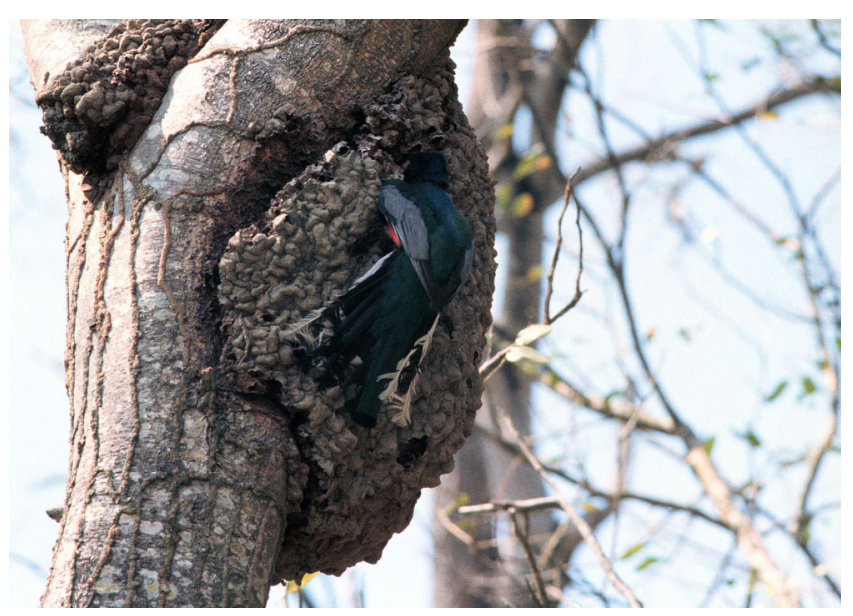

Figure 7. A male of the Surucua Trogon (Trogon surrucura surrucura) digging an arboreal termitarium of Nasutitermes sp. at Morro do Diabo State Park/SP, showing the worning of its rectrices that support him in the termitaria. Photo by Marcelo Ferreira de Vasconcelos.

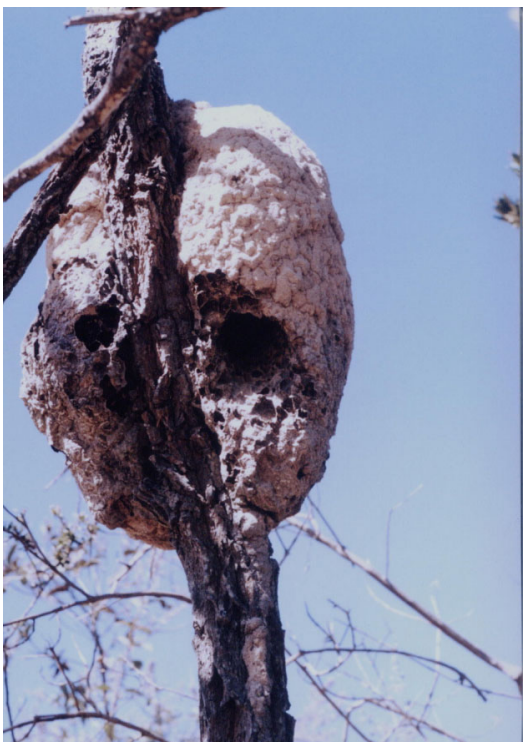

Figure 8. In the cerrado region of Minas Gerais state, the Peach-fronted Parakeet (Eupsittula aurea) is commonly observed nesting in arboreal nests of Constrictotermes cyphergaster. This nest was found in July 2007 in the cerrado of Inhaúma/MG. In its interior it was found a single white and rounded egg. Photo by Marcelo Ferreira de Vasconcelos.

incubatory chamber (Sick 1997) and it remains unchanged even after the nest is abandoned by the birds. Naka (1997) reported that termites also restored the exterior walls damaged in arboreal termitaria which were used for nesting by the Cactus Parakeet (Eupsittula cactorum). In this context, it is noteworthy that parrots have a preference for active termitaria, i.e., those occupied by termites, since abandoned termitaria are very dry and break easily (Hardy 1963).

Sick (1997) mentioned the following bird species that use excavations in termitaria previously made by other birds: the American Kestrel (Falco sparverius), the Tropical Screech-Owl (Megascops choliba), the Ferruginous Pygmy-Owl (Glaucidium brasilianum), the Toco Toucan (Ramphastos toco), the Whiterumped Monjita (Xolmis velatus), the Brown-chested Martin (Progne tapera) and the Chopi Blackbird (Gnorimopsar chopi). In Catalão/GO, R. Silva e Silva (in litt.) photographed one specimen of the Chestnut-eared Aracari (Pteroglossus castanotis) leaving its nest, located in a mound of Cornitermes sp., which was probably dug by another bird. This species can nest in both epigean and in arboreal termitaria (Sick 1997). Bird species reported by Sick (1997) as diggers of holes in termitaria which are later used by other species were parakeets (Psittacidae) and woodpeckers (Picidae), especially the Peachfronted Parakeet and the Campo Flicker (Colaptes campestris). The Burrowing Owl (Athene cunicularia) is also mentioned as an excavator of termite mounds, but also exploits pre-existing holes, so that a couple simply extend it, using their feet and beaks (see Euler 1900, Cunha 1961, Negret \& Teixeira 1983, Sick 1997).

It is also noteworthy that termitaria appear to be a critical resource for maintaining populations of many species of birds that nest in cavities. This is because large trees, which forms potential hollows for nesting-cavity birds, are extremely scarce in secondary forests, as well as in the cerrado of central Brazil (Negret \& Teixeira 1983, MFV pers. obs.). 
Despite birds use termitaria as nest sites, there is a recent report of termites (Microcerotermes cf. exiguus) using an abandoned nest of the Pale-legged Hornero (Furnarius leucopus) in the Caatinga of northeastern Brazil (Silva et al. 2013).

\section{Termitaria as perching sites for Brazilian birds}

Termite mounds can also be used as perching sites for birds. In some cases, these mounds are marked by manure of birds that use them (Fontes 1998a: 218). Thus termitaria provide for birds of prey, such as the Southern Caracara (Caracara plancus) and the Burrowing Owl, strategic points to search for preys in the open landscapes of Brazil, represented the various grassland and savannah natural physiognomies of the cerrado region and man-made pastures (Cunha 1961, Redford 1984, Develey \& Endrigo 2004, Silva e Silva 2004; MFV pers. obs.). Some species also use termitaria as a spot to feed on alates in flight, like the Swallow-tailed Kite (Elanoides forficatus) and the Channel-billed Toucan (Ramphastos vitellinus) (Sick 1997). Importantly, in the cerrado of central Brazil, the termite mounds are important perching sites for two species of endangered birds that are endemic to this region (following Silva 1995, Silva \& Bates 2002, Machado et al. 2005): the White-winged Nightjar (Hydropsalis candicans) and the Campo Miner (Geositta poeciloptera) (Rodrigues et al. 1999, Remsen Jr. 2003, Silva e Silva 2004). The Campo Miner perchs on mound in the cerrado to sing and to perform a wing display which is related to territoriality and attraction of sexual partners (Remsen Jr. 2003). Similar behavior has been recorded for the Red-legged Seriema (Cariama cristata), which perchs on top of mounds of Cornitermes cumulans to vocalize its territorial song (Redford 1984).

\section{Conclusions and perspectives for future researches}

Based on the present review, we conclude that the small number of bird species recorded using termites, for the purposes above described, reflects the lack of observations and the limited published data on natural history. In several bird families recorded in those interactions, other species have the same feeding and breeding habits of the recorded species. Thus, the consumption of termites and the use of termitaria should be more widespread than that reported in the literature. For example, in the families Hirundinidae (swallows) and Apodidae (swifts), with several species represented exclusively by aerial insectivorous, a higher number of species that feed on alates is expected. The same applies to other aerial insectivores, like the nightjars (Caprimulgidae) and tyrant-flycatchers (Tyrannidae). Similarly, it is also expected that many more bird species use termitaria as nest sites or perches in comparison to the current knowledge.

Furthermore, there are other interactions between birds and termites, not addressed in this review, which should be better studied. For example, Sick (1997) mentions that barbets (Capitonidae) hammer termite mounds with their beaks in search for arthropods and that the Lineated Woodpecker (Dryocopus lineatus), puffbirds (Bucconidae) and trogons (Trogonidae), use arboreal termitaria as roosting sites.

The majority of termite species used by Brazilian birds was not identified even at the family or generic levels. This shows a lack of basic natural history information in Brazil. Studies on molecular biology and modeling algorithms are now highly valued, while those on the basic interactions between organisms in nature are declining. Worse, thousands of hectares of native vegetation are destroyed each year in Brazil and we passively watch the biodiversity loss without knowing basic interactions between species. In future studies on termites as food resource or on termitaria as nesting or perching sites for birds, we suggest the collection and identification of these insects. Alates may be easily collected. Sometimes the exit holes can be found in the ground or in the mounds or nests (see Vasconcelos 1999), and this will be an opportunity to also obtain specimens of the soldier caste and the workers, which greatly facilitates the taxonomic identification.

All termite castes (soldiers, workers, nymphs, alates) should be collected preferably with delicate forceps or with small brushes impregnated with alcohol. Termites must be kept in 70$80 \%$ alcohol (Fontes 1995) for later identification with the aid of keys and illustrations (see Mathews 1977, Fontes 1992, 1995, 1998b, Constantino 1999, Milano \& Fontes 2002) or should preferably be sent to taxonomists. It is important to stress that collection should be conducted with permission provided by the Instituto Chico Mendes de Conservação da Biodiversidade (ICMBio), the Brazilian environment agency that deals with scientific collection activities.

Since different species of birds change their foraging behavior when feeding on alates (Eisenmann 1961, Belton 1994, Olson \& Alvarenga 2006; MFV pers. obs.), foraging tactics of each species must be described in detail (see Fitzpatrick 1980, Remsen Jr \& Robinson 1990). Photographs of birds feeding on termites or using termitaria as nesting or perching sites are also recommended in new publications.

Termitaria used by birds as nest sites should be photographed with details of the surface, and eventually one similar mound or nest may be collected or dissected and documented, since the architectural pattern is useful for the recognition of the termite species (see Mathews 1977, Fontes 1995). It is also important to record at the time of the bird nesting, if the mound was active (occupied by termites) or abandoned. Detailed measurements of the nest entrance, the access tunnel and the incubation chamber should be made carefully. It is also desirable to conduct schematic drawings showing the position of the incubation chamber, as well as the direction of the access tunnel inside the termitarium (see Naka 1997). Moreover, it is necessary to study the material that constitutes the incubation chamber (if present) and describe details about the nest according to the recent review on this subject (Simon \& Pacheco 2005). In case of arboreal termitaria, it is always suggested to note its height from the ground, the tree species support and the direction of the nest entrance (north, south, east or west).

Finally, we conclude that there is still a gap in understanding various aspects concerning the natural history and the ecology of interaction between birds and termites. These are some of the challenges that must be faced by naturalists and field biologists in the future.

\section{Acknowledgements}

C. R. M. Abreu, M. Maldonado-Coelho and R. Silva e Silva provided important information based on their personal field observations. L. R. Fontes, L. E. Lopes and two anonymous reviewers made important criticism on the original manuscript. We are also grateful to the Instituto Florestal do Estado de São Paulo for the hospitality in the Morro do Diabo State Park during the IV National Course in Conservation Biology and Wildlife Management, sponsored by the Instituto 
de Pesquisas Ecológicas. S. D'Angelo Neto and L. N. Souza accompanied us on some field trips and made important notes about the behavior of birds feeding on alates. L. E. Lopes, E. Endrigo, R. Silva e Silva, L. R. Fontes and J. F. Pacheco provided important bibliography. MFV is deeply grateful to Conservação Internacional (Project "Fragmentos Florestais APA Fernão Dias") for financial support to conduct fieldwork in the Serra da Mantiqueira. This work is dedicated to termitologists T. A. Gontijo and D. J. Domingos by first advising MFV during his undergraduate research (1993-1995) in Biological Sciences course at Universidade Federal de Minas Gerais (CNPq grant - proccess 101623/1993-3) and for their important studies on the ecology of termites in the cerrados of Minas Gerais.

\section{References}

ADEODATO, A. 2012. WA666626, Trogon curucui Linnaeus, 1766. www.wikiaves.com/666626 (last access at 10/12/2013)

ALEXANDRINO, E.R. 2009. WA83814, Trogon surrucura Vieillot, 1817. www.wikiaves.com/83814 (last access at 10/12/2013)

ALVES, M.A.S. 1991. Dieta e táticas de forrageamento de Neothraupis fasciata em cerrado no Distrito Federal, Brasil (Passeriformes: Emberizidae). Ararajuba 2:25-29.

AMARAL, H.L. 2011. WA483401, Trogon surrucura Vieillot, 1817. www.wikiaves.com/483401 (last access at 10/12/2013)

AMARAL, R.S. 2003. WA238231, Colaptes campestris (Vieillot, 1818). www.wikiaves.com/238231 (last access at 10/12/2013)

ARAUJO, F.M. 2011. WA440048, Eupsittula aurea (Gmelin, 1788). www.wikiaves.com/440048 (last access at 10/12/2013)

ASSIS, C.P., RAPOSO, M.A. \& PARRINI, R. 2007. Validação de Poospiza cabanisi Bonaparte, 1850 (Passeriformes: Emberizidae). Rev. Bras. Ornitol. 15(1):103-112.

AVELINO, E. 2009. WA60226, Colaptes campestris (Vieillot, 1818). www.wikiaves.com/60226 (last access at 10/12/2013)

BELTON, W. 1994. Aves do Rio Grande do Sul:distribuição e biologia. Editora Unisinos, São Leopoldo.

BESSA, R. 2008. WA7541, Tachycineta leucorrhoa (Vieillot, 1817). www.wikiaves.com/7541 (last access at 10/12/2013)

BESSA, R. 2011. WA456296, Colaptes campestris (Vieillot, 1818). www.wikiaves.com/456296 (last access at 10/12/2013)

BETE, D. 2009. WA57343, Colaptes campestris (Vieillot, 1818). www. wikiaves.com/57343 (last access at 10/12/2013)

BIANCHI, C.A., BAUMGARTEN, L. \& ANDRADE, S.M.A. 2000. Cavidades como sítios reprodutivos no cerrado: evidências de competição e partilha de recursos. In Ornitologia brasileira no século XX (incluindo os Resumos do VIII Congresso Brasileiro de Ornitologia) (F.C. Straube, M.M. Argel-De-Oliveira \& J.F. Cândido-Jr, eds). Universidade do Sul de Santa Catarina, Florianópolis, p.299-300.

BIAZOTTO, C.R. 2011. WA457699, Trogon surrucura Vieillot, 1817. www.wikiaves.com/457699 (last access at 10/12/2013)

BIRDLIFE INTERNATIONAL 2000. Threatened birds of the world. BirdLife International \& Barcelona, Cambridge.

BOSO, M. 2010. WA231057, Trogon surrucura Vieillot, 1817. www. wikiaves.com/231057 (last access at 10/12/2013)

BRIGHTSMITH, D.J. 2000. Use of arboreal termitaria by nesting birds in the Peruvian Amazon. Condor 102(3):529-538.

BUCCI, A.D. 2009. WA58374, Colaptes campestris (Vieillot, 1818). www.wikiaves.com/58374 (last access at 10/12/2013)

BUCCI, D. 2010. WA251294, Trogon surrucura Vieillot, 1817. www. wikiaves.com/251294 (last access at 10/12/2013)

BUZZETTI, D.R.C. \& SILVA, S. 2005. Berços da vida: ninhos de aves brasileira. Terceiro Nome, São Paulo.

CAMARGO, J.E. 2010. WA221591, Eupsittula aurea (Gmelin, 1788). www.wikiaves.com/221591 (last access at 10/12/2013)
CARVALHO, A.V. 2010. WA152348, Eupsittula pertinax (Linnaeus, 1758). www.wikiaves.com/152348 (last access at10/12/2013)

CASTRO, M.K. 2000. WA8369, Colaptes campestris (Vieillot, 1818). www.wikiaves.com/8369 (last access at 10/12/2013)

CASTRO, V.G. 2012. WA572959, Notharchus tectus (Boddaert, 1783). www.wikiaves.com/572959 (last access at 10/12/2013)

CBRO. 2014. Lista de Aves do Brasil. Versão 2014. www.cbro.org.br (last access in 12/02/2014)

CEZAR, M. 2010. WA202667, Colaptes campestris (Vieillot, 1818). www.wikiaves.com/202667 (last access at 10/12/2013)

CONSTANTINO, R. 1999. Chave ilustrada para identificação dos gêneros de cupins (Insecta: Isoptera) que ocorrem no Brasil. Pap. Avulsos Zool. (São Paulo) 40(25):387-448.

COSTA-LIMA, A.M. 1938. Insetos do Brasil. Escola Nacional de Agronomia, Rio de Janeiro.

COSTA, S.S. 2008. WA293953, Brotogeris tirica (Gmelin, 1788). www. wikiaves.com/293953 (last access at10/12/2013)

COSTA, S.S. 2009. WA293384, Touit melanonotus (Wied, 1820). www. wikiaves.com/293384 (last access at 10/12/2013)

COSTA, T.C. 2011. WA421369, Eupsittula aurea (Gmelin, 1788). www. wikiaves.com/421369 (last access at 10/12/2013)

COUTO, J. 2010. WA267635, Pyrrhura frontalis (Vieillot, 1817). www. wikiaves.com/267635 (last access at 10/12/2013)

COUTO, P.H. 2011. WA530951, Tachycineta leucorrhoa (Vieillot, 1817). www.wikiaves.com/530951 (last access at 10/12/2013)

CUNHA, J.G. 2010a. WA181460, Brotogeris chiriri (Vieillot, 1818). www.wikiaves.com/181460 (last access at 10/12/2013)

CUNHA, L.M. 2010b. WA147520, Primolius maracana (Vieillot, 1816). www.wikiaves.com/147520 (last access at 10/12/2013)

CUNHA, O.R. 1961. Mundo estranho: a vida dos cupins. Irmãos Pongetti, Rio de Janeiro.

CZABAN, R.E. 2003. WA83477, Bucco tamatia Gmelin, 1788. www. wikiaves.com/83477 (last access at 10/12/2013)

DALESSANDRO, R. 2010. WA170786, Eupsittula aurea (Gmelin, 1788). www.wikiaves.com/170786 (last access at 10/12/2013)

DE BONT, A.F. 1964. Termites et densité d'oiseaux. In Etudes sur les termites africains (A. Bouillon, ed). Masson, Paris, p. 273-283.

DEVELEY, P.F. \& ENDRIGO, E. 2004. Aves da Grande São Paulo: guia de campo. Aves e Fotos Editora, São Paulo.

DIAL, K.P. \& VAUGHAN, T.A. 1987. Opportunistic predation on alate termites in Kenya. Biotropica 19(2):185-187, http://dx.doi.org/ $10.2307 / 2388744$

DUBS, B. 1992. Birds of southwestern Brazil: catalogue and guide to the birds of the Pantanal of Mato Grosso and its border areas. Betrona-Verlag, Küsnacht.

EISENMANN, E. 1961. Favorite foods of Neotropical birds: flying termites and Cecropia catkins. Auk 78(4):636-638, http://dx.doi.org/ $10.2307 / 4082198$

EULER, C. 1900. Descripção de ninhos e ovos das aves do Brasil. Rev. Mus. Paulista 4:9-148.

FARIA, I.P. 2007. Peach-fronted parakeet (Aratinga aurea) feeding on arboreal termites in the Brazilian cerrado. Rev. Bras. Ornitol. 15(3):457-458.

FILHO, U.B. 2011. WA532435, Colaptes campestris (Vieillot, 1818). www.wikiaves.com/532435 (last access at 10/12/2013)

FITZPATRICK, J.W. 1980. Foraging behavior of Neotropical tyrant flycatchers. Condor 82(1):43-57, http://dx.doi.org/10.2307/1366784

FLORES, F.M. 2010. WA207539, Brotogeris chiriri (Vieillot, 1818). www.wikiaves.com/207539. (last access at 10/12/2013)

FONTES, L.R. 1992. Key to the genera of New World Apicotermitinae (Isoptera: Termitidae). In Insects of Panamá and Mesoamerica: selected studies (D. Quintero \& A. Aiello, eds). Oxford University Press, Oxford, p. 242-248.

FONTES, L.R. 1995. Sistemática geral de cupins. In Alguns aspectos atuais da biologia e controle de cupins (E. Berti Filho \& L.R. Fontes, eds). FEALQ, Piracicaba, p. 11-17. 
FONTES, L.R. 1998a. Cupins nas pastagens do Brasil: algumas indicações de controle. In Cupins: o desafio do conhecimento (L.R. Fontes \& E. Berti Filho, eds). FEALQ, Piracicaba, p. 211-225.

FONTES, L.R. 1998b. Novos aditamentos ao "Catálogo dos Isoptera do Novo Mundo", e uma filogenia para os gêneros neotropicais de Nasutitermitinae. In Cupins: o desafio do conhecimento (L.R. Fontes \& E. Berti Filho, eds). FEALQ, Piracicaba, p. 309-412.

GONZAGA, L.P. 1991. In memoriam: Helmut Sick. Ararajuba 2:107115.

GUEDES, M.A. 2009. WA59776, Tachycineta leucorrhoa (Vieillot, 1817). www.wikiaves.com/59776 (last access at 10/12/2013)

GUSSONI, C.O.A. \& CAMPOS, R.P. 2003. Registro de uma grande concentração de aves se alimentando de "aleluias" (Isoptera). Lundiana 4(1):71.

HANSCH, L.A. 2011. WA490480, Trogon surrucura Vieillot, 1817. www.wikiaves.com/490480 (last access at 10/12/2013)

HARDY, J.W. 1963. Epigamic and reproductive behavior of the orange-fronted parakeet. Condor 65(3):169-199.

HEMPEL, A. 1949. Estudo da alimentação natural de aves silvestres do Brasil. Arq. Inst. Biolog. 19:237-268.

KOK, O.B., KOK, A.C. \& VANEE, C.A. 2000. Diet of the migrant Lesser Kestrels Falco naumanni in their winter quarters in South Africa. Acta Ornithol. 35(2):147-151, http://dx.doi.org/10.3161/ 068.035 .0207

KONZE, J.C. 2010. WA205318, Trogon surrucura Vieillot, 1817. www. wikiaves.com/205318 (last access at 10/12/2013)

KOPIJ, G. 2000. Diet of swifts (Apodidae) and swallows (Hirundinidae) during the breeding season in South African grassland. Acta Ornithol. 35(2):203-206, http://dx.doi.org/10.3161/ 068.035 .0201

LICCO, S.C. 2010. WA233355, Trogon surrucura Vieillot, 1817. www. wikiaves.com/233355 (last access at 10/12/2013)

LIMA, R.D. 2012. WA684609, Brotogeris chiriri (Vieillot, 1818). www. wikiaves.com/684609 (last access at 10/12/2013)

LOPES, L.E., FERNANDES, A.M. \& MARINI, M.Â. 2005. Diet of some Atlantic Forest birds. Ararajuba 13(1):95-103.

LUCCIA, V.P. 2011. WA462781, Trogon surrucura Vieillot, 1817. www.wikiaves.com/462781 (last access at 10/12/2013)

MACHADO, A.B.M., MARTINS, C.S. \& DRUMMOND, G.M. 2005. Lista da fauna brasileira ameaçada de extinção: incluindo as listas das espécies quase ameaçadas e deficientes em dados. Fundação Biodiversitas, Belo Horizonte.

MALLET-RODRIGUES, F. 2001. Foraging and diet composition of the black-capped foliage gleaner (Philydor atricapillus). Ornitol. Neotrop. 12(3):255-264.

MARANTZ, C.A., ALEIXO, A., BEVIER, L.R. \& PATTEN, M.A. 2003. Family Dendrocolaptidae (woodcreepers). In Handbook of the birds of the world (J. Del Hoyo, A. Elliott \& D.A. Christie, eds). Lynx Edicions, Barcelona v. 8, p. 358-447.

MARTINS, M. \& EGLER, S.G. 1990. Comportamento de caça em um casal de corujas buraqueiras (Athene cunicularia) na região de Campinas, São Paulo, Brasil. Rev. Bras. Biol. 50(3):579-584.

MARTIUS, C., BANDEIRA, A.G. \& MEDEIROS, L.G.S. 1996. Variation in termite alate swarming in rain forests of central Amazonia. Ecotropica 2(1):1-11.

MATHEWS, A.G.A. 1977. Studies on termites from the Mato Grosso State, Brazil. Academia Brasileira de Ciências, Rio de Janeiro.

MAZZONI, L.G., CANUTO, M., GOMES, V.M. \& RODRIGUES, V.C. 2013. Notes on the breeding biology of the Pied Puffbird Notharchus tectus in southeastern Pará, Brazil. Atual. Ornitol. 171:24-25

MEDEIROS, L.G.S., BANDEIRA, A.G. \& MARTIUS, C. 1999. Termite swarming in the northeastern Atlantic rain forest of Brazil. Stud. Neotrop. Fauna Environ. 34(2):76-87, http://dx.doi.org/ 10.1076/snfe.34.2.76.2103

MELO-JÚNIOR, T.A. 2001. Comportamento alimentar de Jacamaralcyon tridactyla (Galbuliformes, Galbulidae), em duas reservas no Estado de Minas Gerais. In Ornitologia sem fronteiras (incluindo os Resumos do IX Congresso Brasileiro de Ornitologia) (F.C. Straube, ed). Pontifícia Universidade Católica do Paraná, Curitiba, p. 277-278.

MENQ, W. 2009. WA54382, Trogon surrucura Vieillot, 1817. www. wikiaves.com/54382 (last access at 10/12/2013)

MILANO, S. \& FONTES, L.R. 2002. Cupim e cidade: implicações ecológicas e controle. Edição dos autores, São Paulo.

MOOJEN, J., CARVALHO, J.C. \& LOPES, H.S. 1941. Observações sobre o conteúdo gastrico das aves brasileiras. Mem. Inst. Oswaldo Cruz 36(3):405-444, http://dx.doi.org/10.1590/S0074-02761941000 300016

MOTTA, C.A. 2011. WA527971, Trogon surrucura Vieillot, 1817. www.wikiaves.com/527971 (last access at 10/12/2013)

NAKA, L.N. 1997. Nest and egg description of an endemism of the Brazilian north-east: the cactus parakeet, Aratinga cactorum. Ararajuba 5(2):182-185.

NEGRET, J.A. \& TEIXEIRA, D.M. 1983. O uso de termiteiros para a nidificação de algumas aves do Planalto Central. In Resumos do X Congresso Brasileiro de Zoologia. Universidade Federal de Minas Gerais, Belo Horizonte, p. 348-349.

NETTO, A. 2010a. WA97858, Eupsittula cactorum (Kuhl, 1820). www. wikiaves.com/97858 (last access at 10/12/2013)

NETTO, A. 2010b. WA110000, Eupsittula cactorum (Kuhl, 1820). www.wikiaves.com/110000 (last access at 10/12/2013)

NETTO, A. 2010c. WA218354, Eupsittula cactorum (Kuhl, 1820). www.wikiaves.com/218354 (last access at 10/12/2013)

NETTO, A. 2010d. WA266067, Eupsittula cactorum (Kuhl, 1820). www.wikiaves.com/266067 (last access at 10/12/2013)

NUTTING, W.L. 1969. Flight and colony foundation. In Biology of termites (K. Krishna \& F.M. Weesner, eds). Academic Press, New York v. 1, p. 233-282.

OLIVEIRA-FILHO, A.T. 1992a. Floodplain 'murundus' of Central Brazil: evidence for the termite-origin hypothesis. J. Trop. Ecol. 8(1):1-19, http://dx.doi.org/10.1017/S0266467400006027

OLIVEIRA-FILHO, A.T. 1992b. The vegetation of Brazilian 'murundus' - the island-effect on the plant community. J. Trop. Ecol. 8(4):465-486, http://dx.doi.org/10.1017/S0266467400006817

OLIVEIRA, D.M. 2010a. WA237339, Progne chalybea (Gmelin, 1789). www.wikiaves.com/237339 (last access at 10/12/2013)

OLIVEIRA, D.R. 2011. WA443672, Eupsittula aurea (Gmelin, 1788). www.wikiaves.com/443672 (last access at 10/12/2013)

OLIVEIRA, J.C. 2010b. WA221232, Trogon surrucura Vieillot, 1817. www.wikiaves.com/221232 (last access in 10/12/2013)

OLSON, S.L. \& ALVARENGA, H. 2006. An extraordinary feeding assemblage of birds at a termite swarm in the Serra da Mantiqueira, São Paulo, Brazil. Rev. Bras. Ornitol. 14(3):297-299.

OLYNTHO, M.S. 2011. WA417501, Eupsittula aurea (Gmelin, 1788). www.wikiaves.com/417501 (last access at 10/12/2013)

PACHECO, J.F. 1995a. Notulae et corrigenda. Atual. Ornitol. 66:10.

PACHECO, J.F. 1995b. Notulae et corrigenda II. Atual. Ornitol. 67:10.

PAIVA, C.L. 1998. Cupins e o patrimônio histórico edificado. In Cupins: o desafio do conhecimento (L.R. Fontes \& E. Berti Filho, eds). FEALQ, Piracicaba, p. 133-162.

PENHA, J.M.F. 1995. Alimentação de Rhynchotus rufescens na serra de São Vicente, município de Santo Antônio de Leverger, Mato Grosso (Tinamiformes: Tinamidae). Ararajuba 3:55-56.

PEREIRA, H. 2010a. WA209056, Trogon surrucura Vieillot, 1817. www.wikiaves.com/209056 (last access at 10/12/2013)

PEREIRA, L.G. 2010b. WA254562, Trogon surrucura Vieillot, 1817. www.wikiaves.com/254562 (last access at 10/12/2013)

RASO, T.T. 2008. WA11849, Brotogeris chiriri (Vieillot, 1818). www. wikiaves.com/11849. (last access at 10/12/2013)

REDFORD, K.H. 1984. The termitaria of Cornitermes cumulans (Isoptera, Termitidae) and their role in determining a potential keystone species. Biotropica 16(2):112-119, http://dx.doi.org/ $10.2307 / 2387842$ 
REMSEN JR, J.V \& ROBINSON, S.K. 1990. A classification scheme for foraging behavior of birds in terrestrial habitats. Stud. Avian Biol. 13:144-160.

REMSEN JR.J.V. 2003. Family Furnariidae (ovenbirds). In Handbook of the birds of the world, v. 8 (J. Del Hoyo, A. Elliott \& D.A. Christie, eds). Lynx Edicions, Barcelona, p.162-357.

RIBAS, C.F. 2010. WA494935, Trogon viridis Linnaeus, 1766. www. wikiaves.com/494935 (last access at 10/12/2013)

RIBEIRO, V.M. 2012. WA669775, Eupsittula aurea (Gmelin, 1788). www.wikiaves.com/669775 (last access at 10/12/2013)

RIEDTMANN, Z. 2011. WA513634, Trogon surrucura Vieillot, 1817. www.wikiaves.com/513634 (last access at 10/12/2013)

RODRIGUES, F.E. 2009. WA54894, Colaptes campestris (Vieillot, 1818). www.wikiaves.com/54894. (last access at 10/12/2013)

RODRIGUES, F.H.G., HASS, A., MARINI FILHO, OJ., GUIMARÃES, M.M. \& BAGNO, M.A. 1999. A new record of White-winged Nightjar Caprimulgus candicans in Emas National Park, Goiás, Brazil. Cotinga 11:83-85.

RODRIGUES, M. \& COSTA, L.M. 2006. Diversidade e conservação de aves na Serra do Cipó, Minas Gerais. Atual. Ornitol. 130:28-31.

SALAZAR, L.F \& COSTA, L.M. 2012. WA596533, Trogon surrucura Vieillot, 1817. www.wikiaves.com/596533. (last access at 10/12/ 2013).

SALES, M.M. 2011. WA431775, Eupsittula aurea (Gmelin, 1788). www.wikiaves.com/431775 (last access at 10/12/2013)

SANSON, P. 2010. WA200998, Trogon surrucura Vieillot, 1817. www. wikiaves.com/200998 (last access at 10/12/2013)

SANTOS, D.W. 2007. WA89944, Colaptes campestris (Vieillot, 1818). www.wikiaves.com/89944 (last access at 10/12/2013)

SANTOS, D.W. 2008. WA87863, Brotogeris chiriri (Vieillot, 1818). www.wikiaves.com/87863 (last access at 10/12/2013)

SANTOS, K. 2009. WA56373, Trogon surrucura Vieillot, 1817. www. wikiaves.com/56373 (last access at 10/12/2013)

SAZIMA, I. 1989. Peach-fronted Parakeet feeding on winged termites. Wilson Bull. 101(4):656-657.

SAZIMA, I. 2008. Dancing in the rain: swarms of winged termites congregate a varied bird assemblage at an urban backyard in southeastern Brazil. Rev. Bras. Ornitol. 16(4):402-405.

SCHUBART, O., AGUIRRE, Á.C. \& SICK, H. 1965. Contribuição para o conhecimento da alimentação das aves brasileiras. Arq. Zool. (São Paulo) 12:95-249.

SI, L.P. 2010. WA363938, Trogon surrucura Vieillot, 1817. www. wikiaves.com/363938. (last access at 10/12/2013)

SICK, H. 1965. A fauna do Cerrado. Arq. Zool. (São Paulo) 12:71-92.

SICK, H. 1997. Ornitologia brasileira. Nova Fronteira, Rio de Janeiro.

SILVA E SILVA, R. 2004. Magia do Cerrado: aves na imensidão. Dórea Books and Art, São Paulo.

SILVA E SILVA, R. 2005. Biologia reprodutiva de Geositta poeciloptera (Passeriformes: Furnariidae) em Minas Gerais. In Resumos do XIII Congresso Brasileiro de Ornitologia. Universidade Federal do Pará, Belém, p. 28.

SILVA, J.G. 2004. WA101826, Trogon surrucura Vieillot, 1766. www. wikiaves.com/101826 (last access at 10/12/2013)

SILVA, J.M.C. 1995. Biogeographic analysis of the South American Cerrado avifauna. Steenstrupia 21(1):49-67.
SILVA, J.M.C. \& BATES, J.M. 2002. Biogeographic patterns and conservation in the South American Cerrado: atropical savanna hotspot. Bioscience 52(3):225-234, http://dx.doi.org/10.1641/00063568(2002)052[0225:BPACIT]2.0.CO;2

SIlVA, L.B., COUTO, A.A.V.O., ARRUDA, A.R., SILVA, J.S. \& MOURA, C.C.M. 2013. Utilização de ninho de Furnarius leucopus (Passeriformes: Furnariidae) por Microcerotermes cf. exiguus (Isoptera: Termitidae) na Caatinga, nordeste do Brasil. Atual. Ornitol. 175:26.

SILVEIRA, M. 2010. WA105882, Trogon curucui Linnaeus, 1766. www.wikiaves.com/105882 (last access at 10/12/2013)

SILVESTRI, F. 1903. Contribuzione alla conoscenza dei termiti e termitofili dell'America Meridionale. Redia 1(1):1-234.

SIMON, J.E. \& PACHECO, S. 2005. On the standardization of nest descriptions of neotropical birds. Rev. Bras. Ornitol. 13(2):7-18.

SOARES, R.M. 2010. WA118230, Trogon curucui Linnaeus, 1766. www.wikiaves.com/118230 (last access at 10/12/2013)

SONNTAG, F.A. 2011. WA623142, Touit surdus (Kuhl, 1820). www. wikiaves.com/623142 (last access at 10/12/2013)

STAMATO, M. 2009. WA22918, Eupsittula aurea (Gmelin, 1788). www.wikiaves.com/22918 (last access at 10/12/2013)

TEIXEIRA, D.M. 1987. Notas sobre o "gravatazeiro", Rhopornis ardesiaca (Wied, 1831) (Aves, Formicariidae). Rev. Bras. Biol. 47(3):409-414.

TEIXEIRA, D.M. \& NEGRET, A. 1984. The dwarf tinamou (Taoniscus nanus) of Central Brazil. Auk 101(1):188-189.

TEIXEIRA, P.M. 2010. WA107448, Eupsittula cactorum (Kuhl, 1820). www.wikiaves.com/107448 (last access at 10/12/2013)

THIOLLAY, J.-M. 1970. L'exploitation par les oiseaux des essaimages de fourmis et termites dans une zone de contact savane-forêt en Côte-D'Ivoire. Alauda 38:255-273.

VASCONCELOS, M.F. 1999. Cupins alados (Neocapritermes sp.) como alimento do tico-tico, Zonotrichia capensis. Atual. Ornitol. 87:12.

VASCONCELOS, M.F., D'ANGELO NETO, S., KIRWAN, G.M., BORNSCHEIN, M.R., DINIZ, M.G., \& SILVA, J.F. 2006. Important ornithological records from Minas Gerais state, Brazil. Bull. Br. Ornithol. Club 126(3):212-238.

VASCONCELOS, M.F., FIGUEREDO, C.C. \& OLIVEIRA, R.S. 1999. Táticas de forrageamento do bacurau-da-telha Caprimulgus longirostris (Aves, Caprimulgidae) na Serra do Curral, Minas Gerais, Brasil. Bol. Mus. Biol. Mello Leitao Nova Ser. 10:33-38.

VIEIRA, V.C. 2011. WA470574, Colaptes campestris (Vieillot, 1818). www.wikiaves.com/470574 (last access at 10/12/2013)

VON IHERING, H. 1900. Catálogo crítico-comparativo dos ninhos e ovos das aves do Brasil. Rev. Mus. Paulista 4:191-300.

VON IHERING, H. 1914. Novas contribuições para a ornithologia do Brazil. Rev. Mus. Paulista 9:411-448.

WIED-NEUWIED, M. 1821. Reise nach Brasilien in den Jahren 1815 bis 1817. Brönner, Frankfurt.

ZACHETTI, U. 2010. WA250626, Colaptes campestris (Vieillot, 1818). www.wikiaves.com/250626 (last access at 10/12/2013).

ZIMER, M.S. 2010. WA223410, Trogon surrucura Vieillot, 1817. www. wikiaves.com/223410 (last access at 10/12/2013). 